\title{
Study on the Formation of Antihypertensive Twin Drugs by Caffeic Acid and Ferulic Acid with Telmisartan
}

This article was published in the following Dove Press journal: Drug Design, Development and Therapy

\author{
Pengshou $\mathrm{Li}^{1}$ \\ Yingying Peng' \\ Qixiang $\mathrm{Ma}^{2}$ \\ Ziyong Li $\mathbb{B}^{\prime}$ \\ Xiaohua Zhang ${ }^{3}$
}

'Department of Food Science and Engineering, School of Food and Drug, Luoyang Normal University, Luoyang 471 934, People's Republic of China; ${ }^{2}$ Cancer Institute, Fudan University Cancer Hospital and Cancer Metabolism Laboratory, Institutes of Biomedical Sciences, Fudan University, Shanghai 200032, People's Republic of China; ${ }^{3}$ Department of Traditional Chinese Medicine and Pharmacy, School of Chinese Materia Medica, Beijing University of Chinese Medicine, Beijing 100102, People's Republic of China
Correspondence: Xiaohua Zhang School of Chinese Materia Medica, Beijing University of Chinese Medicine, No. II, Bei San Huan Dong Lu, Chaoyang District, Beijing 100102 , People's Republic of China $\mathrm{Tel} / \mathrm{Fax}+86-10-8473-8668$

Email xhua_zhang@sina.com
Purpose: This study aimed to synthesize twin drugs from cinnamic acid compounds, caffeic acid (CFA) and ferulic acid (FLA), which can antagonize endothelin-1 (ET-1) with telmisartan through ester bonds. Moreover, the antihypertensive effect of telmisartan and its influence on blood pressure variability (BPV) were enhanced, and the bioavailability of caffeic acid and ferulic acid was improved.

Methods: Six twin drugs, which were the target compounds, were synthesized. Hypertensive rats (SHR) and conscious sinoaortic-denervated (SAD) rats were spontaneously used as models for pharmacodynamic research to study the antihypertensive efficacy of these twin drugs. Wistar rats were employed as pharmacokinetic research models to investigate the pharmacokinetics of the target compounds via intragastric administration. Cellular pharmacodynamic research was also conducted on the antagonistic action on Ang IIAT1, ETA and ETB receptor.

Results: Compound 1a was determined as the best antihypertensive twin drug and thus was further studied for its effect on BPV. Compared with that of telmisartan, the antihypertensive effect of compound 1a was improved $(p<0.05)$, and the BPV was reduced $(p<0.05)$. The bioavailability of caffeic acid and ferulic acid after hydrolysis from twin drugs could be increased to varying degrees, and the differences of the main pharmacokinetic parameters among the different forms of caffeic acid and ferulic acid were statistically significant $(p<0.05$ or $p<0.01)$. Compound 1a had the best antagonistic effect on the Ang II-AT1 receptor. However, the $\mathrm{IC}_{50}$ of Lps-2 was still two orders of magnitude higher than that of the positive drug telmisartan. Hence, the twin drugs worked by metabolizing and regenerating telmisartan and caffeic acid or ferulic acid in the body.

Conclusion: The synthesized twin drugs improved telmisartan's antihypertensive effects, significantly decreased BPV in SAD rats and increased the bioavailability of caffeic acid and ferulic acid. This study serves as a basis for the development of new angiotensin receptor blocker $(\mathrm{ARB})$ in the future and a reference for the development of new drugs to antagonize ET-1.

Keywords: ferulic acid, caffeic acid, twin drugs, telmisartan, pharmacokinetics, pharmacodynamics

\section{Introduction}

Telmisartan is an angiotensin II receptor antagonist and has a strong antihypertensive effect, but telmisartan is not a good suppressor of blood pressure fluctuations during antihypertensive process. ${ }^{1-4}$ High blood pressure variability (BPV) is an important cause of cardiovascular diseases and can cause damage to the target organs of hypertension. ${ }^{5-7}$ 
Endothelin 1 (ET-1), which has a strong contraction of blood vessels, could promote the mitotic effect of smooth muscle cells, and is closely related to a variety of heart and cerebrovascular disease. ${ }^{8,9}$ Studies had evaluated the antagonistic effects of caffeic acid and ferulic acid on the biological effects of ET-1 at the level of overall animals, isolated organs, cells and subcells. Results showed that caffeic acid and ferulic acid had an antagonistic biological effect on ET-1. ${ }^{10-13}$ However, the molecular weight of caffeic acid and ferulic acid is small, and their half-life in the body is very short ${ }^{14-17}$ at only $0.5-1 \mathrm{~h}$, because the polarity of caffeic acid and ferulic acid is very large, thus greatly reducing the absorption and metabolic process, and the rate of binding to plasma protein is very low. However, the bioavailability of caffeic acid could increase significantly after the caffeic acid is esterified with some compounds. $^{18}$

A twin drug is a new molecule that connects two identical or different lead compounds or drugs through a covalent bond. Twin drugs could reproduce the two drugs in the body to produce synergies and enhance the activity or produce new pharmacological activities or increase the selectivity of the activities, and improve the pharmacokinetic properties or reduce side effects.

Caffeic acid and ferulic acid do not have obvious toxic effects, and they have antagonistic activity of ET-1. Therefore, the combination of caffeic acid and ferulic acid with telmisartan through covalent bond to form twin drugs increases one target (ET-1) that acts on the onset of hypertension, which could deal with the multiple mechanisms of hypertension. They could also reduce blood pressure variability during telmisartan's antihypertensive process by forming twin drugs with telmisartan. In addition, the half-life of caffeic acid and ferulic acid could be increased, and their bioavailability could be improved. We have studied the pharmacodynamics and pharmacokinetics of these twin drugs. These results would provide references for the development of new antihypertensive drugs.

\section{Materials and Methods}

\section{General Information}

All reactions were monitored by thin-layer chromatography (TLC) on silica gel GF-254 plates purchased from Qingdao Haiyang Corporation. Proton nuclear magnetic resonance $\left({ }^{1} \mathrm{H}-\mathrm{NMR}\right)$ and carbon-13 $\left({ }^{13} \mathrm{C}\right)$-NMR spectra were acquired using a Bruker AV500 $\mathrm{MHz}$ spectrometer, and DMSO- $d_{6}, \mathrm{CDCl}_{3}, \mathrm{CD}_{3} \mathrm{OD}$ were used as the solvent.
Chemical shifts are reported in parts per million shift $(\delta$ value) based on $\mathrm{Me}_{4} \mathrm{Si}\left(\delta 0 \mathrm{ppm}\right.$ for $\left.{ }^{1} \mathrm{H}\right)$. High-resolution mass spectra (HR-MS) were acquired using a Thermo Scientific LTQ Orbitrap XL (New York, NY, USA). Telmisartan (Jiangsu Zhongbang Pharmaceutical Co., Ltd.), caffeic acid, ferulic acid and protocatechuic aldehyde (Hubei Yuanchenggongchuang Co., Ltd.), Vanillin (Beijing Chemical Works). Melting points (m.p., uncorrected) were measured using an X-5 micro melting point apparatus (Beijing, China). Silica-gel column chromatography was performed using 200-300 mesh silica gel purchased from Qingdao Haiyang Corporation. The yields were calculated based on the last step of the reaction. All chemicals and solvents used were analytical or highperformance liquid chromatography grade. HC-2518 High Speed Centrifuge (Anhui Zhongke Zhongjia Science Instrument Co., Ltd.). XW-80A Vortex Mixer (Shanghai Medical University Instrument Factory). PH Meter (German Sartorius). CH-300 Ultrasonic Cleaner (Beijing Institute of Innovative Ultrasonic Electronics). The data were given as means \pm SEM. Comparison between experimental groups was made by using one-way ANOVA, followed by student Newman Keuls test. $p$ values $<0.05$ or $<0.01$ were considered significant difference or extremely distinct difference (SPSS (PASW) 17.0).

\section{Chemistry}

\section{Synthesis of Compounds 3, 4 and 7, 8}

Ferulic acid $(0.583 \mathrm{~g}, 0.003 \mathrm{~mol})$ was dissolved in $10 \mathrm{~mL}$ methanol/ethanol, and then added $0.2 \mathrm{~mL}$ concentrated sulfuric acid and $1 \mathrm{~g}$ anhydrous sodium sulfate and then the mixture was stirred under reflux for $6 \mathrm{~h}$. After the reaction was over, cooled to room temperature, and added $0.6 \mathrm{~g}$ anhydrous $\mathrm{K}_{2} \mathrm{CO}_{3}$ to neutralize the sulfuric acid, and decompressed to remove methanol/ethanol. The residue was dissolved with ethyl acetate, filtered, and collected the filtrate. The filtrate was washed 3 times in $25 \%$ sodium bicarbonate solution, and the ethyl acetate layer was dried with anhydrous $\mathrm{Na}_{2} \mathrm{SO}_{4}$, and then decompressed to remove ethyl acetate. The residues were recrystallized with anhydrous methanol.

The synthesis of compounds 7,8 was similar to compounds 3, 4 .

Ferulic acid methyl ester (3). The product was obtained as a white solid $(77.02 \%$ yield $)$; m.p. $160.5 \sim 162.2^{\circ} \mathrm{C}$. ${ }^{1} \mathrm{H}-\mathrm{NMR}\left(\mathrm{CDCl}_{3}\right) \delta(\mathrm{ppm}): 7.63(\mathrm{~d}, J=15.9 \mathrm{~Hz}, 1 \mathrm{H}$, H-7), 7.07 (dd, $J=8.2,1.5 \mathrm{~Hz}, 1 \mathrm{H}, \mathrm{H}-6), 7.02$ (s, 1H, 
H-2), $6.92(\mathrm{~d}, J=8.2 \mathrm{~Hz}, 1 \mathrm{H}, \mathrm{H}-5), 6.30(\mathrm{~d}, J=15.9 \mathrm{~Hz}$, $1 \mathrm{H}, \mathrm{H}-8), 6.21$ (s, $1 \mathrm{H},-\mathrm{OH}), 3.91$ (s, 3H, $\left.-\mathrm{OCH}_{3}\right), 3.80$ (s, $\left.3 \mathrm{H},-\mathrm{OCH}_{3}\right) ;{ }^{13} \mathrm{C}-\mathrm{NMR}\left(\mathrm{DMSO}-d_{6}\right) \delta(\mathrm{ppm}): 167.54(\mathrm{C}-9)$, 149.84 (C-4), 148.40 (C-3), 145.53 (C-1), 126.04 (C-Ph), 123.52 (C-Ph), 116.01 (C-Ph), 114.69 (C-7), 111.81 (C-8), $55.93\left(-\mathrm{OCH}_{3}\right), \quad 51.70\left(-\mathrm{OCH}_{3}\right) . \quad \mathrm{HRMS} \quad(\mathrm{ESI}) \mathrm{m} / \mathrm{z}$ : 209.08367[M+H $\left.{ }^{+}\right]$, calcd. for $\mathrm{C}_{11} \mathrm{H}_{13} \mathrm{O}_{4} 209.08138$.

Ferulic acid ethyl ester (4). The product was obtained as a white solid $(74.40 \%$ yield $)$; m.p. $155.5 \sim 157.5^{\circ} \mathrm{C}$. ${ }^{1} \mathrm{H}-\mathrm{NMR}\left(\mathrm{DMSO}-d_{6}\right) \delta(\mathrm{ppm}): 9.62(\mathrm{~s}, 1 \mathrm{H}, 4-\mathrm{OH}), 7.55$ (d, $J=15.9 \mathrm{~Hz}, 1 \mathrm{H}, \mathrm{H}-7), 7.32$ (t, $J=11.1 \mathrm{~Hz}, 1 \mathrm{H}, \mathrm{H}-2)$, 7.12 (dd, $J=8.2,1.6 \mathrm{~Hz}, 1 \mathrm{H}, \mathrm{H}-6), 6.80$ (d, $J=8.1 \mathrm{~Hz}$, $1 \mathrm{H}, \mathrm{H}-5), 6.48$ (d, $J=15.9 \mathrm{~Hz}, 1 \mathrm{H}, \mathrm{H}-8), 4.11-4.22$ (m, $2 \mathrm{H}, \mathrm{H}-10), 3.80$ (s, 3H, H-12), 1.29-1.18 (m, 3H, $\mathrm{CH}_{3}$ -11); ${ }^{13} \mathrm{C}-\mathrm{NMR}$ (DMSO- $d_{6}$ ) $\delta$ (ppm): 167.08 (C-9), 149.79 (C-4), 148.41 (C-3), 145.35 (C-1), 126.08 (Ph-C), 123.53 (Ph-C), 115.98 (Ph-C), 115.05 (C-7), 111.70 (C-8), 60.14 (C-12), 56.16 (C-10), 14.70 (C-11). HRMS (ESI) m/z: 223.09841[M+ $\left.\mathrm{H}^{+}\right]$, calcd. for $\mathrm{C}_{12} \mathrm{H}_{15} \mathrm{O}_{4} 223.09704$.

Caffeic acid methyl ester (7). The product was obtained as a Pale yellow solid (77.77\% yield); m.p. 164.8 166. ${ }^{\circ} \mathrm{C}$. ${ }^{1} \mathrm{H}-\mathrm{NMR}\left(\mathrm{CD}_{3} \mathrm{OD}\right) \delta(\mathrm{ppm}): 7.55$ (d, $J=$ $15.9 \mathrm{~Hz}, 1 \mathrm{H}, \mathrm{H}-7), 7.05$ (d, $J=1.8 \mathrm{~Hz}, 1 \mathrm{H}, \mathrm{H}-2), 6.94$ (dd, $J=8.2,1.8 \mathrm{~Hz}, 1 \mathrm{H}, \mathrm{H}-6), 6.79$ (d, $J=8.2 \mathrm{~Hz}, 1 \mathrm{H}, \mathrm{H}-5)$, 6.26 (d, $J=15.9 \mathrm{~Hz}, 1 \mathrm{H}, \mathrm{H}-8), 4.96$ (s, 2H, 2个-OH), 3.76 $\left(\mathrm{s}, 3 \mathrm{H},-\mathrm{OCH}_{3}\right) ;{ }^{13} \mathrm{C}-\mathrm{NMR}$ (DMSO- $\left.d_{6}\right) \delta$ (ppm): 167.46 (C-9), 148.89 (C-3), 146.04 (C-4), 145.62 (C-1), 125.97 (Ph-C), 121.87 (Ph-C), 116.20 (Ph-C), 115.26 (C-7), 114.17 (C-8), 51.70 (C-10). HRMS (ESI) m/z: 195.06942 $\left[\mathrm{M}+\mathrm{H}^{+}\right]$, calcd. for $\mathrm{C}_{10} \mathrm{H}_{11} \mathrm{O}_{4} 195.06573$.

Caffeic acid ethyl ester (8). The product was obtained as a Pale yellow solid (77.77\% yield); m.p. 151.85 152.98 ${ }^{\circ} \mathrm{C} .{ }^{1} \mathrm{H}-\mathrm{NMR}$ (DMSO- $\left.d_{6}\right) \delta$ (ppm): 9.38 (s, 2H, 3,4-OH), 7.48 (d, $J=15.9 \mathrm{~Hz}, 1 \mathrm{H}, \mathrm{H}-7$ ), 7.06 (d, $J=1.9 \mathrm{~Hz}, 1 \mathrm{H}, \mathrm{H}-2), 7.00$ (dd, $J=8.2,1.9 \mathrm{~Hz}, 1 \mathrm{H}, \mathrm{H}-6)$, 6.79 (t, $J=11.5 \mathrm{~Hz}, 1 \mathrm{H}, \mathrm{H}-5), 6.27$ (d, $J=15.9 \mathrm{~Hz}, 1 \mathrm{H}$, $\mathrm{H}-8$ ), 4.11-4.18 (m, 2H, H-10), 1.20-1.27 (m, 3H, H-11); ${ }^{13} \mathrm{C}-\mathrm{NMR}$ (DMSO- $\left.d_{6}\right) \delta$ (ppm): 166.94 (C-9), 148.83 (C-3), 145.28 (C-4), 143.87 (C-1), 126.01 (Ph-C), 121.78 (Ph-C), 116.21 (Ph-C), 115.18 (C-7), 114.20 (C-8), 40.45 (C-10), 14.70 (C-11). HRMS (ESI) m/z: 209.08149[M $+\mathrm{H}^{+}$], calcd. for $\mathrm{C}_{11} \mathrm{H}_{13} \mathrm{O}_{4} 209.08138$.

\section{Synthesis of Compounds Ia-Id}

Synthesis of Compound 1a: Compound 3 (0.314g, $0.0015 \mathrm{~mol})$, telmisartan $(0.515 \mathrm{~g}, 0.001 \mathrm{~mol}), \quad \mathrm{DCC}$ $(0.309 \mathrm{~g}, 0.0015 \mathrm{~mol})$, and DMAP $(0.366 \mathrm{~g}, 0.003 \mathrm{~mol})$ were dissolved in $30 \mathrm{~mL} \mathrm{DCM}$, and the mixture was heated to $80^{\circ} \mathrm{C}$ under stirring for $4 \mathrm{~h}$. After the reaction was over, the system was cooled to room temperature and decompressed to remove solvent. The crude material was then purified in a 200-300 mesh silica column (petroleum ether:ethyl acetate:methanol, 20:10:3).

The ester of telmisartan and ferulic acid methyl ester (1a). The product was obtained as a white solid $(45.28 \%$ yield); m.p. $261.2 \sim 263.9^{\circ} \mathrm{C} .{ }^{1} \mathrm{H}-\mathrm{NMR}\left(\mathrm{CDCl}_{3}\right) \delta$ (ppm): 8.10 (d, $J=7.6 \mathrm{~Hz}, 1 \mathrm{H}, \mathrm{Ph}-\mathrm{H}), 7.79-7.84$ (m, 1H, Ph-H), 7.60 (dd, $J=12.3,3.7 \mathrm{~Hz}, 2 \mathrm{H}, \mathrm{Ph}-\mathrm{H}), 7.45-7.51$ (m, 2H, Ph-H), 7.44 (s, 1H, Ph-H), 7.37 (d, J=7.9 Hz, 3H, Ph-H), 7.28 (ddd, $J=15.9,8.2,4.6 \mathrm{~Hz}, 3 \mathrm{H}, \mathrm{Ph}-\mathrm{H}, \mathrm{H}-7$ ') 7.11 (d, $J=8.0 \mathrm{~Hz}, 2 \mathrm{H}, \mathrm{Ph}-\mathrm{H}), 7.00$ (d, $J=8.4 \mathrm{~Hz}, 2 \mathrm{H}, \mathrm{Ph}-\mathrm{H})$, 6.86 (d, $J=7.9 \mathrm{~Hz}, 1 \mathrm{H}, \mathrm{Ph}-\mathrm{H}), 6.35$ (d, $J=16.0 \mathrm{~Hz}, 1 \mathrm{H}$, H-8'), 5.44 (d, $J=13.1 \mathrm{~Hz}, 2 \mathrm{H}, \mathrm{H}-14), 3.83$ (s, 3H, 9'$\left.\mathrm{OCH}_{3}\right), 3.75\left(\mathrm{~s}, 3 \mathrm{H},-\mathrm{CH}_{3}\right), 3.66\left(\mathrm{~s}, 3 \mathrm{H},-\mathrm{CH}_{3}\right), 2.88-2.95$ $\left(\mathrm{m}, 2 \mathrm{H},-\mathrm{CH}_{2^{-}}\right), 2.79\left(\mathrm{~s}, 3 \mathrm{H},-\mathrm{CH}_{3}\right), 1.82-1.91(\mathrm{~m}, 2 \mathrm{H},-$ $\left.\mathrm{CH}_{2}-\right), 1.04$ (t, $\left.J=7.3 \mathrm{~Hz}, 3 \mathrm{H},-\mathrm{CH}_{3}\right) ;{ }^{13} \mathrm{C}-\mathrm{NMR}\left(\mathrm{CDCl}_{3}\right)$ $\delta$ (ppm): 167.15 (C-1), 166.92 (Ph-C), 165.40 (C-9'), 156.40 (C-16), 154.54 (C-28), 151.47 (Ph-C), 143.96 (Ph-C), 143.21 (Ph-C), 143.11 (Ph-C), 142.68 (Ph-C), 141.38 (Ph-C), 140.79 (Ph-C), 136.64 (Ph-C), 134.99 (Ph-C), 134.65 (Ph-C), 133.37 (Ph-C), 132.08 (Ph-C), 131.07 (Ph-C), 130.71 (Ph-C), 129.55 (Ph-C), 129.38 (Ph-C), 129.23 (two Ph-C), 127.52 (Ph-C), 125.84 (two $\mathrm{Ph}-\mathrm{C}$ ), 123.97 (Ph-C), 122.94 (Ph-C), 122.49 (Ph-C), 122.29 (Ph-C), 121.04 (Ph-C), 119.50 (Ph-C), 118.09 (C-7’), 111.24 (C-8'), 109.51 (Ph-C), 108.82 (Ph-C), 55.79 (C-11'), 51.17 (C-10'), 47.05 (C-14), 31.74 (C-37), 29.83 (C-17), 21.82 (C-18), 16.85 (C-27), 14.07(C-19). HRMS (ESI) m/z: 705.30292[M+H $\left.{ }^{+}\right]$, calcd. for $\mathrm{C}_{44} \mathrm{H}_{41} \mathrm{~N}_{4} \mathrm{O}_{5} 705.30770$.

Synthesis of Compound 1b: Compound 4 (0.333g, $0.0015 \mathrm{~mol})$, telmisartan $(0.515 \mathrm{~g}, 0.001 \mathrm{~mol}), \quad \mathrm{DCC}$ $(0.309 \mathrm{~g}, 0.0015 \mathrm{~mol})$, and DMAP $(0.366 \mathrm{~g}, 0.003 \mathrm{~mol})$ were dissolved in $30 \mathrm{~mL} \mathrm{THF}$, and the mixture was heated to $80^{\circ} \mathrm{C}$ under stirring for $4 \mathrm{~h}$. After the reaction was over, the system was cooled to room temperature, and decompressed to remove solvent. The crude material was then purified in a 200-300 mesh silica column (petroleum ether:ethyl acetate:methanol, 20:10:3), and the resulting solid was finally re-crystallized with anhydrous ethanol.

The ester of telmisartan and ferulic acid ethyl ester (1b). The product was obtained as a white solid $(57.32 \%$ yield); m.p. $254.2 \sim 256.9^{\circ} \mathrm{C} .{ }^{1} \mathrm{H}-\mathrm{NMR}\left(\mathrm{CDCl}_{3}\right) \delta$ (ppm): 8.09 (d, $J=7.6 \mathrm{~Hz}, 1 \mathrm{H}, \mathrm{Ph}-\mathrm{H}), 7.80$ (d, $J=7.3 \mathrm{~Hz}, 1 \mathrm{H}$, Ph-H), 7.59 (dd, $J=12.3,3.7 \mathrm{~Hz}, 2 \mathrm{H}, \mathrm{Ph}-\mathrm{H}), 7.43-7.50$ (m, 2H, Ph-H), 7.32-7.40 (m, 4H, Ph-H), 7.25 (dd, $J=$ 
16.5, 7.1 Hz, 3H, Ph-H, 7'-H), 7.10 (d, $J=8.0$ Hz, 2H, PhH), 6.97-7.03 (m, 2H, Ph-H), 6.85 (d, $J=8.0 \mathrm{~Hz}, 1 \mathrm{H}, \mathrm{Ph}-$ H), 6.35 (d, $J=16.0 \mathrm{~Hz}, 1 \mathrm{H}, \mathrm{H}-8$ '), 5.41 (s, 2H, H-14), $3.76\left(\mathrm{~d}, J=13.7 \mathrm{~Hz}, 3 \mathrm{H},-\mathrm{CH}_{3}\right), 3.61(\mathrm{~d}, J=14.5 \mathrm{~Hz}, 3 \mathrm{H}$, $\left.-\mathrm{CH}_{3}\right), 3.47\left(\mathrm{~d}, J=16.1 \mathrm{~Hz}, 2 \mathrm{H},-\mathrm{CH}_{2}-\right), 2.88-2.94(\mathrm{~m}$, $\left.2 \mathrm{H},-\mathrm{CH}_{2}-\right), 2.78\left(\mathrm{~s}, 3 \mathrm{H},-\mathrm{CH}_{3}\right), 1.79-1.92\left(\mathrm{~m}, 2 \mathrm{H},-\mathrm{CH}_{2}-\right)$, $1.36\left(\mathrm{t}, J=7.1 \mathrm{~Hz}, 3 \mathrm{H},-\mathrm{CH}_{3}\right), 0.99-1.07\left(\mathrm{~m}, 3 \mathrm{H},-\mathrm{CH}_{3}\right)$; ${ }^{13} \mathrm{C}-\mathrm{NMR}\left(\mathrm{CDCl}_{3}\right) \delta(\mathrm{ppm}): 166.77(\mathrm{C}-1), 166.69(\mathrm{Ph}-\mathrm{C})$, 165.44 (C-9'), 156.46 (C-16), 154.48 (C-28), 151.44 (PhC), 143.71 (Ph-C), 143.68 (Ph-C), 143.14 (Ph-C), 142.67 (Ph-C), 141.29 (Ph-C), 140.79 (Ph-C), 136.58 (Ph-C), 134.92 (Ph-C), 134.87 (Ph-C), 133.45 (Ph-C), 132.11 (Ph-C), 131.00 (Ph-C), 130.73 (Ph-C), 129.62 (Ph-C), 129.37 (Ph-C), 129.19 (two Ph-C), 127.48 (Ph-C), 125.92 (two Ph-C), 123.64(Ph-C), 122.92 (Ph-C), 122.55 (Ph-C), 122.36 (Ph-C), 121.04 (Ph-C), 119.42 (Ph-C), 118.55 (C-7'), 111.14 (C-8'), 109.57 (Ph-C), 108.95 (PhC), 60.59 (C-12'), 55.79 (C-10'), 47.05 (C-14), 31.79 (C-37), 29.75 (C-17), 21.85 (C-18), 16.88 (C-27), 14.35 (C-11'), 14.08 (C-19). HRMS (ESI) m/z: 719.32478[M $+\mathrm{H}^{+}$], calcd. for $\mathrm{C}_{45} \mathrm{H}_{43} \mathrm{~N}_{4} \mathrm{O}_{5} 719.32335$.

The synthesis of compounds 1c, 1d was similar to compounds $\mathbf{1 a}, \mathbf{1 b}$.

The ester of telmisartan and caffeic acid methyl ester (1c). The product was obtained as a white solid $(56.28 \%$ yield); m.p. $263.1 \sim 265.8^{\circ} \mathrm{C} .{ }^{1} \mathrm{H}-\mathrm{NMR}\left(\mathrm{CDCl}_{3}\right) \delta$ (ppm): $7.98(\mathrm{~d}, J=7.5 \mathrm{~Hz}, 1 \mathrm{H}, \mathrm{H}-3), 7.67$ (d, $J=7.6 \mathrm{~Hz}, 1 \mathrm{H}$, H-6), 7.57 (dd, $J=14.1,6.2 \mathrm{~Hz}, 2 \mathrm{H}, \mathrm{H}-4,5), 7.52$ (s, 1H, H-25), 7.47 (d, $J=7.6 \mathrm{~Hz}, 3 \mathrm{H}, \mathrm{H}-23,31,34), 7.39$ (d, $J=6.6 \mathrm{~Hz}, 1 \mathrm{H}, \mathrm{H}-33), 7.34$ (d, $J=10.0 \mathrm{~Hz}, 2 \mathrm{H}, \mathrm{H}-9$, 13), 7.27 (d, $J=13.6 \mathrm{~Hz}, 3 \mathrm{H}, \mathrm{H}-8,31,32), 7.20$ (d, $J=$ $6.9 \mathrm{~Hz}, 2 \mathrm{H}, \mathrm{H}-10,12), 7.09$ (d, $J=8.3 \mathrm{~Hz}, 1 \mathrm{H}, \mathrm{H}-6$ '), 6.99 (d, $J=8.2 \mathrm{~Hz}, 1 \mathrm{H}, \mathrm{H}-5$ '), 6.19 (d, $J=15.9 \mathrm{~Hz}, 1 \mathrm{H}$, H-7'), 5.37 (s, 2H, H-14), 3.82 (s, 3H, H-10'), 3.78 (s, $3 \mathrm{H}, \mathrm{H}-37), 3.04$ (t, $J=7.8 \mathrm{~Hz}, 2 \mathrm{H}, \mathrm{H}-17), 2.75$ (s, 3H, H-27), 1.84-2.02 (m, 2H, H-18), 1.10 (t, $J=7.6 \mathrm{~Hz}, 3 \mathrm{H}$, $\mathrm{H}-19) ;{ }^{13} \mathrm{C}-\mathrm{NMR}\left(\mathrm{CDCl}_{3}\right) \delta(\mathrm{ppm}): 167.76(\mathrm{C}-1), 166.63$ (C-9'), 166.46 (Ph-C), 156.48 (C-16), 154.52 (C-28), 152.13 (Ph-C), 149.52 (Ph-C), 144.40 (Ph-C), 143.22 (Ph-C), 141.87 (Ph-C), 141.20 (Ph-C), 140.90 (Ph-C), 140.72 (Ph-C), 138.90 (Ph-C), 136.15 (Ph-C), 135.01 (Ph-C), 134.36 (Ph-C), 131.66 (Ph-C), 130.72 (Ph-C), 130.19 (Ph-C), 129.57 (Ph-C), 129.27 (Ph-C), 129.12 (two Ph-C), 127.45 (Ph-C), 127.06 (Ph-C), 126.39 (two $\mathrm{Ph}-\mathrm{C}), 123.37$ (Ph-C), 122.93 (Ph-C), 122.07 (Ph-C), 118.93 (Ph-C), 118.61 (Ph-C), 117.06 (Ph-C), 116.37 (C-7'), 114.74 (C-8'), 51.55 (C-10'), 47.36 (C-14), 31.86 (C-37), 29.66 (C-17), 22.00 (C-18), 16.95 (C-27),
14.07 (C-19). HRMS (ESI) m/z: 691.28926[M+H $\left.{ }^{+}\right]$, calcd. for $\mathrm{C}_{43} \mathrm{H}_{39} \mathrm{~N}_{4} \mathrm{O}_{5} 691.29205$.

The ester of telmisartan and caffeic acid ethyl ester (1d). The product was obtained as a white solid $(54.34 \%$ yield); m.p. 249.6 252.4 ${ }^{\circ} \mathrm{C} .{ }^{1} \mathrm{H}-\mathrm{NMR}\left(\mathrm{CDCl}_{3}\right) \delta$ (ppm): 7.99 (dd, $J=6.3,5.6 \mathrm{~Hz}, 1 \mathrm{H}, \mathrm{Ph}-\mathrm{H}), 7.73$ (d, $J=7.3 \mathrm{~Hz}$, 1H, Ph-H), 7.53 (dt, $J=19.8,11.7$ Hz, 2H, Ph-H, H-7'), 7.46 (d, $J=5.1 \mathrm{~Hz}, 1 \mathrm{H}, \mathrm{Ph}-\mathrm{H}), 7.36-7.45$ (m, 3H, PhH), $7.32(\mathrm{dd}, J=9.3,7.1 \mathrm{~Hz}, 4 \mathrm{H}, \mathrm{Ph}-\mathrm{H}), 7.20$ (d, $J=1.9$ $\mathrm{Hz}, 1 \mathrm{H}, \mathrm{Ph}-\mathrm{H}$ ), 7.10 (dd, $J=12.0,8.2 \mathrm{~Hz}, 2 \mathrm{H}, \mathrm{Ph}-\mathrm{H}$ ), 6.93-6.99 (m, 1H, Ph-H), 6.83 (dd, $J=10.4,2.0 \mathrm{~Hz}, 1 \mathrm{H}$, Ph-H), 6.69 (d, $J=8.4$ Hz, 1H, Ph-H), 6.17 (d, $J=15.9$ Hz, 1H, H-8'), 5.28 (d, $J=19.1 \mathrm{~Hz}, 2 \mathrm{H}, \mathrm{H}-14), 4.18-$ $4.26\left(\mathrm{~m}, 2 \mathrm{H},-\mathrm{CH}_{2}-\right), 3.75\left(\mathrm{~d}, J=12.3 \mathrm{~Hz}, 3 \mathrm{H},-\mathrm{CH}_{3}\right)$, 2.87-2.96 (m, 2H, $-\mathrm{CH}_{2}$ ), $2.70\left(\mathrm{~s}, 3 \mathrm{H},-\mathrm{CH}_{3}\right), 1.83$ (dq, $\left.J=15.2,7.5 \mathrm{~Hz}, 2 \mathrm{H},-\mathrm{CH}_{2}-\right), 1.28-1.33\left(\mathrm{~m}, 3 \mathrm{H},-\mathrm{CH}_{3}\right)$, $1.01\left(\mathrm{td}, J=7.3,4.4 \mathrm{~Hz}, 3 \mathrm{H},-\mathrm{CH}_{3}\right) ;{ }^{13} \mathrm{C}-\mathrm{NMR}\left(\mathrm{CDCl}_{3}\right)$ $\delta$ (ppm): 167.33 (C-1), 166.98 (C-9'), 166.33 (Ph-C), 156.53 (C-16), 154.43 (C-28), 152.07 (Ph-C), 149.68 (Ph-C), 144.07 (Ph-C), 143.03 (Ph-C), 142.02 (Ph-C), 141.34 (Ph-C), 140.86 (Ph-C), 140.53 (Ph-C), 139.01 (Ph-C), 136.17 (Ph-C), 134.94 (Ph-C), 134.44 (Ph-C), 132.66 (Ph-C), 131.71 (Ph-C), 130.83 (Ph-C), 130.57 (Ph-C), 130.10 (Ph-C), 129.31 (two Ph-C), 127.42 (PhC), 127.08 (Ph-C), 126.31 (two $\mathrm{Ph}-\mathrm{C}$ ), 125.52 (Ph-C), 123.56 (Ph-C), 122.87 (Ph-C), 122.11 (Ph-C), 117.59 (Ph-C), 117.16 (Ph-C), 116.38 (C-7'), 115.30 (C-8'), 60.34 (C-10’), 47.26 (C-14), 31.81 (C-37), 29.59 (C-17), 21.91 (C-18), 16.92 (C-27), 14.34 (C-11'), 14.04 (C-19). HRMS (ESI) $\mathrm{m} / \mathrm{z}: 705.30218\left[\mathrm{M}+\mathrm{H}^{+}\right]$, calcd. for $\mathrm{C}_{44} \mathrm{H}_{41} \mathrm{~N}_{4} \mathrm{O}_{5} 705.30770$.

\section{Synthesis of Compounds Ie-If}

Synthesis of Compound 11: Telmisartan $(0.515 \mathrm{~g}, 0.001 \mathrm{~mol})$, DCC (0.309g, 0.0015mol), DMAP (0.244g, 0.002mol) and vanillin $(0.228 \mathrm{~g}, 0.0015 \mathrm{~mol})$ were dissolved in DCM $30 \mathrm{~mL}$, and the mixture was stirred under reflux for $4 \mathrm{~h}$. After the reaction was over, the system was cooled to room temperature, and decompressed to remove solvent. The crude material was then purified in a 200-300 mesh silica column (petroleum ether:ethyl acetate:methanol, 20:10:3), and the resulting solid was finally re-crystallized with anhydrous ethanol. The product was obtained as a white solid (73.37\% yield); m.p. $241.4 \sim 243.8^{\circ} \mathrm{C}$.

Synthesis of Compound 1e: Compound 11 (0.649g, $0.001 \mathrm{~mol})$, malonic acid $(0.208 \mathrm{~g}, 0.002 \mathrm{~mol})$, pyridine $1.0 \mathrm{~mL}$, aniline $0.2 \mathrm{~mL}$ were dissolved in THF $20 \mathrm{~mL}$, and the mixture was then stirred at $105^{\circ} \mathrm{C}$ for $4 \mathrm{~h}$. After the 
reaction was over, the system was cooled to room temperature, and decompressed to remove solvent. The crude material was then purified in a 200-300 mesh silica column (petroleum ether:ethyl acetate:methanol, 20:10:3) to remove aniline and pyridine, and then eluted using dichloromethane: methanol $=10: 1$. The resulting solid was finally re-crystallized with anhydrous ethanol.

The ester of telmisartan and ferulic acid (1e). The product was obtained as a white solid (40.81\% yield); m.p. 262.5 264. $8^{\circ} \mathrm{C}$. ${ }^{1} \mathrm{H}-\mathrm{NMR}$ (DMSO- $\left.d_{6}\right) \delta$ (ppm): 12.01-12.85 (m, 1H, 9'-COOH), 7.97 (d, $J=7.6$ Hz, 1H, Ph-H), 7.76 (s, 1H, Ph-H), 7.66-7.71 (m, 1H, Ph-H), 7.57 (t, $J=$ $7.4 \mathrm{~Hz}, 1 \mathrm{H}, \mathrm{Ph}-\mathrm{H}), 7.48$ (dd, $J=16.0,8.2 \mathrm{~Hz}, 5 \mathrm{H}, \mathrm{Ph}-\mathrm{H}$, H-7'), 7.40 (t, $J=11.4$ Hz, 3H, Ph-H), 7.20-7.27 (m, 4H, $\mathrm{Ph}-\mathrm{H}), 7.11$ (d, $J=8.1 \mathrm{~Hz}, 1 \mathrm{H}, \mathrm{Ph}-\mathrm{H}), 6.92$ (d, $J=8.1 \mathrm{~Hz}$, 1H, Ph-H), 6.56 (d, $\left.J=16.0 \mathrm{~Hz}, 1 \mathrm{H}, \mathrm{H}-8^{\prime}\right), 5.64$ (s, 2H, $\mathrm{H}-14), 3.75$ (d, $\left.J=11.4 \mathrm{~Hz}, 6 \mathrm{H},-\mathrm{CH}_{3},-\mathrm{OCH}_{3}\right), 2.90$ (t, $J=$ $\left.7.5 \mathrm{~Hz}, 2 \mathrm{H},-\mathrm{CH}_{2^{-}}\right), 2.64\left(\mathrm{~s}, 3 \mathrm{H},-\mathrm{CH}_{3}\right), 1.78$ (dt, $J=15.0$, $\left.7.5 \mathrm{~Hz}, 2 \mathrm{H},-\mathrm{CH}_{2}-\right), 0.95\left(\mathrm{t}, J=7.3 \mathrm{~Hz}, 3 \mathrm{H},-\mathrm{CH}_{3}\right)$; ${ }^{13} \mathrm{C}-\mathrm{NMR}$ (DMSO- $\left.d_{6}\right) \delta$ (ppm): 168.96 (C-9'), 168.05 (C-1), 165.81 (Ph-C), 156.75 (C-16), 154.13 (C-28), 151.60 (Ph-C), 143.70 (Ph-C), 143.02 (Ph-C), 142.04 (PhC), 140.94 (Ph-C), 139.89 (Ph-C), 136.75 (Ph-C), 136.06 (Ph-C), 135.09 (Ph-C), 133.90 (Ph-C), 132.77 (Ph-C), 131.34 (Ph-C), 130.56 (Ph-C), 129.72 (Ph-C), 129.45 (two Ph-C), 128.75 (Ph-C), 128.15 (Ph-C), 126.95 (two Ph-C), 123.86 (Ph-C), 123.21 (Ph-C), 122.79 (Ph-C), 122.60 (Ph-C), 121.63 (Ph-C), 120.09 (Ph-C), 118.77 (Ph-C), 112.23 (C-7'), 110.98 (C-8'), 109.79 (Ph-C), 108.45 (PhC), 56.39 (C-10'), 46.52 (C-14), 32.21 (C-37), 29.15 (C-17), 21.15 (C-18), 16.93 (C-27), 14.26 (C-19). HRMS (ESI) $\mathrm{m} / \mathrm{z}: \quad 691.29481\left[\mathrm{M}+\mathrm{H}^{+}\right]$, calcd. for $\mathrm{C}_{43} \mathrm{H}_{39} \mathrm{~N}_{4} \mathrm{O}_{5}$ 691.29205 .

Synthesis of Compound 12: Telmisartan (0.515g, $0.001 \mathrm{~mol})$, DCC $(0.309 \mathrm{~g}, 0.0015 \mathrm{~mol})$, DMAP $(0.244 \mathrm{~g}$, $0.002 \mathrm{~mol})$ and protocatechuic aldehyde $(0.207 \mathrm{~g}$, $0.0015 \mathrm{~mol}$ ) were dissolved in THF $30 \mathrm{~mL}$, and the mixture was stirred under reflux for $4 \mathrm{~h}$. After the reaction was over, the system was cooled to room temperature, and decompressed to remove solvent. The crude material was then purified in a 200-300 mesh silica column (petroleum ether:ethyl acetate:methanol, 20:10:3), and the resulting solid was finally re-crystallized with anhydrous ethanol. The product was obtained as a white solid (71.99\% yield); m.p. $223.6 \sim 226.3^{\circ} \mathrm{C}$.

Synthesis of Compound 1f: Compound $12(0.635 \mathrm{~g}$, $0.001 \mathrm{~mol})$, malonic acid $(0.208 \mathrm{~g}, 0.002 \mathrm{~mol})$, pyridine $1.0 \mathrm{~mL}$, aniline $0.2 \mathrm{~mL}$ were dissolved in THF $20 \mathrm{~mL}$, and the mixture was then stirred at $105^{\circ} \mathrm{C}$ for $4 \mathrm{~h}$. After the reaction was over, the system was cooled to room temperature, and decompressed to remove solvent. The crude material was then purified in a 200-300 mesh silica column (petroleum ether:ethyl acetate:methanol, 20:10:3) to remove aniline and pyridine, and then eluted using dichloromethane: methanol $=10: 1$. The resulting solid was finally re-crystallized with anhydrous ethanol.

The ester of telmisartan and caffeic acid (1f). The product was obtained as a white solid (47.14\% yield); m.p. 271.5 273.1 ${ }^{\circ} \mathrm{C} .{ }^{1} \mathrm{H}-\mathrm{NMR}$ (DMSO- $\left.d_{6}\right) \delta(\mathrm{ppm}): 12.57$ (s, 1H, 9'-COOH), 8.01 (dd, $J=20.6,7.7$ Hz, 1H, Ph-H), 7.76 (d, $\left.J=17.8 \mathrm{~Hz}, 2 \mathrm{H}, \mathrm{Ph}-\mathrm{H}, \mathrm{H}-7^{\prime}\right), 7.69$ (t, $J=7.5 \mathrm{~Hz}, 1 \mathrm{H}$, Ph-H), 7.64 (d, $J=7.7 \mathrm{~Hz}, 1 \mathrm{H}, \mathrm{Ph}-\mathrm{H}), 7.57$ (t, $J=7.6 \mathrm{~Hz}$, 1H, Ph-H), 7.33-7.55 (m, 8H, Ph-H), 7.20-7.29 (m, 4H, Ph-H), 6.34 (dd, $J=15.9,3.1 \mathrm{~Hz}, 1 \mathrm{H}, \mathrm{H}-8$ ') 5.64 (s, 2H, $\mathrm{H}-14), 3.75$ (d, $\left.J=3.6 \mathrm{~Hz}, 3 \mathrm{H},-\mathrm{CH}_{3}\right), 2.90$ (dd, $J=15.8$, $\left.8.2 \mathrm{~Hz}, 2 \mathrm{H},-\mathrm{CH}_{2}-\right), 2.64$ (d, $\left.J=5.5 \mathrm{~Hz}, 3 \mathrm{H},-\mathrm{CH}_{3}\right), 1.78$ (dt, $\left.\mathrm{J}=22.2,7.6 \mathrm{~Hz}, 2 \mathrm{H},-\mathrm{CH}_{2}-\right), 0.94(\mathrm{dd}, \mathrm{J}=13.4,6.1 \mathrm{~Hz}, 3 \mathrm{H}$, $\left.\mathrm{CH}_{3}\right) ;{ }^{13} \mathrm{C}-\mathrm{NMR}$ (DMSO- $\left.d_{6}\right) \delta$ (ppm): 168.96 (C-9'), 168.25 (C-1), 165.83 (Ph-C), 156.86 (C-16), 154.03 (C-28), 151.71 (Ph-C), 149.32 (Ph-C), 144.67 (Ph-C), 143.75 (Ph-C), 142.95 (Ph-C), 142.15 (Ph-C), 141.47 (PhC), 139.98 (Ph-C), 139.05 (Ph-C), 136.58 (Ph-C), 135.04 (Ph-C), 134.91 (Ph-C), 134.58 (Ph-C), 132.72 (Ph-C), 131.09 (Ph-C), 130.32 (Ph-C), 129.93 (Ph-C), 129.60 (two Ph-C), 128.84 (Ph-C), 128.43 (Ph-C), 126.88 (two Ph-C), 126.26 (Ph-C), 123.98 (Ph-C), 123.74 (Ph-C), 122.88 (PhC), 118.58 (Ph-C), 117.41 (Ph-C), 117.04 (C-7'), 116.46 (C-8'), 46.57 (C-14), 32.23 (C-37), 29.11 (C-17), 21.13 (C-18), 16.92 (C-27), 14.20 (C-19). HRMS (ESI) m/z: $677.28193\left[\mathrm{M}+\mathrm{H}^{+}\right]$, calcd. for $\mathrm{C}_{42} \mathrm{H}_{37} \mathrm{~N}_{4} \mathrm{O}_{5} 677.27640$.

\section{Biological Activity}

\section{Study on Antihypertensive Activity in vivo}

These experimental procedures complied with regulations of the National Institutes of Health (NIH) of USA and conducted in accordance with the guidance of the Animal Ethics Committee of Beijing University of Chinese Medicine. The study protocol was approved by the Animal Ethics Committee of Beijing University of Chinese Medicine. Sixteen-week-old, male SHR and Wistar rats $(250 \mathrm{~g} \pm 20 \mathrm{~g})$ were purchased from the institute of Beijing Vital River Laboratory Animal Technology Co., Ltd. (Beijing, China). Before use in the study, all the rats were acclimatized in a controlled room at a constant temperature $\left(23 \pm 2^{\circ} \mathrm{C}\right)$ and humidity $(60 \pm 5 \%)$ on a $12 \mathrm{~h}$ light/dark cycle and provided with standard diet and water for one week. 
The 80 SHR rats were randomly divided into ten groups, each group of 8 , and the other group was Wistar rats, 8 . Six groups of SHR rats were given the test drug of $\mathbf{1 a}, \mathbf{1 b}, \mathbf{1 c}$, 1d, 1e, 1f by intragastric administration, and they were the test groups; One group of SHR rats was given the positive drug telmisartan + ferulic acid by intragastric administration, which was the positive group 1; One group of SHR rats was given the positive drug telmisartan + caffeic acid by intragastric administration, which was the positive group 2; One group of SHR rats was given the positive drug telmisartan by intragastric administration, which was the positive group 3; One group of SHR rats was given the water by intragastric administration, and it was the model group. The group of Wistar rats were given the water by intragastric administration, which was the blank group. Give medicine or water at 10 a.m. every morning. We determined the blood pressure in SHR rats and Wistar rats before intragastric administration. After a week of continuous intragastric administration of drugs or water, the blood pressure in SHR rats and Wistar rats were tested. The blood pressure was measured by noninvasive blood pressure for mice and rat's system (Softron BP-98A, Softron Biotechnology, Beijing, China).

Amount of medicine given (Figure 1):

(a) compound 1a: $15.65 \mathrm{mg} / \mathrm{kg}(0.022 \mathrm{mmol} / \mathrm{kg})$;

(b) compound $1 \mathrm{~b}: 15.97 \mathrm{mg} / \mathrm{kg}(0.022 \mathrm{mmol} / \mathrm{kg})$;

(c) compound 1c: $15.34 \mathrm{mg} / \mathrm{kg}(0.022 \mathrm{mmol} / \mathrm{kg})$;

(d) compound 1d: $15.65 \mathrm{mg} / \mathrm{kg}(0.022 \mathrm{mmol} / \mathrm{kg})$;

(e) compound 1e: $15.34 \mathrm{mg} / \mathrm{kg}(0.022 \mathrm{mmol} / \mathrm{kg})$; (f) compound 1f: $15.03 \mathrm{mg} / \mathrm{kg}(0.022 \mathrm{mmol} / \mathrm{kg})$;

(g) Positive group 1: telmisartan $11.43 \mathrm{mg} / \mathrm{kg}(0.022 \mathrm{mmol} /$ $\mathrm{kg})+$ ferulic acid $4.31 \mathrm{mg} / \mathrm{kg}(0.022 \mathrm{mmol} / \mathrm{kg})$;

(h) Positive group 2: telmisartan $11.43 \mathrm{mg} / \mathrm{kg}(0.022 \mathrm{mmol} /$ $\mathrm{kg})+$ caffeic acid $4.00 \mathrm{mg} / \mathrm{kg}(0.022 \mathrm{mmol} / \mathrm{kg})$;

(i) Positive group 3: telmisartan $11.43 \mathrm{mg} / \mathrm{kg}(0.022 \mathrm{mmol} /$ $\mathrm{kg})$.

The 40 SHR rats were randomly divided into 5 groups, each group of 8 , and the other group was Wistar rats, 8 . Two groups of SHR rats were given the test drugs of compound 12 and ethyl ester of telmisartan by intragastric administration, and they were the test groups. Two groups of SHR rats were given the positive drugs, and they were the positive groups. One group of SHR rats was given the water by intragastric administration, it was the model group. The group of Wistar rats was given the water by intragastric administration, which was the blank group. The blood pressure was measured by noninvasive blood pressure for mice and rat's system (Softron BP-98A, Softron Biotechnology, Beijing, China).

Amount of medicine given (Figure 2):

(a) Test group 1: compound 12: $13.95 \mathrm{mg} / \mathrm{kg}(0.022 \mathrm{mmol} /$ $\mathrm{kg}$ );

(b) Positive group 1: telmisartan $11.43 \mathrm{mg} / \mathrm{kg}(0.022 \mathrm{mmol} /$ $\mathrm{kg})+$ protocatechuic aldehyde $3.04 \mathrm{mg} / \mathrm{kg}(0.022 \mathrm{mmol} /$ $\mathrm{kg})$.

(c) Test group 2: ethyl ester of telmisartan $11.93 \mathrm{mg} / \mathrm{kg}$ $(0.022 \mathrm{mmol} / \mathrm{kg})$

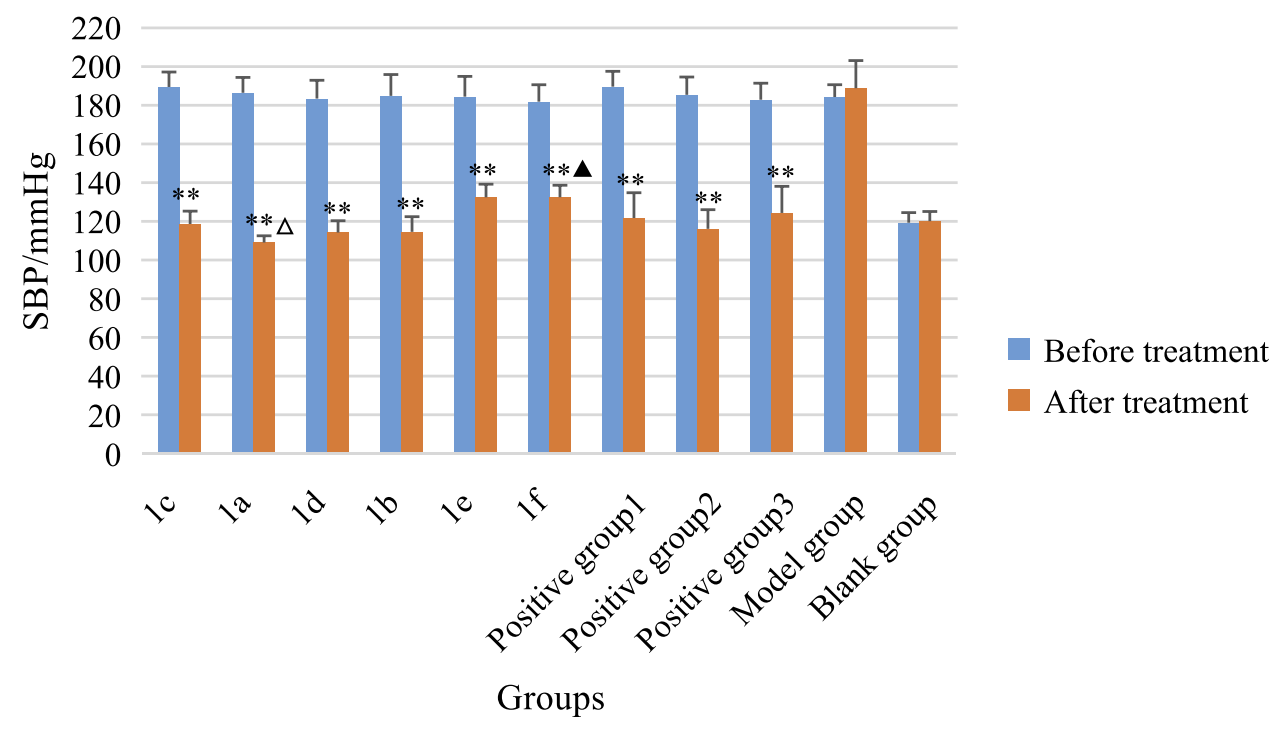

Figure I The antihypertensive effect of compounds Ia-If. The differences between the before and after treatment of these groups were statistically significant (denoted by ** for $p<0.01$ ); The differences of antihypertensive effect between test group and positive group I or positive group 2 were statistically significant (denoted by $\mathbf{A}$ for $p<0.05$ ); The differences of antihypertensive effect between test group and positive group 3 were statistically significant (denoted by “\$”'for $p<0.05$ ). 


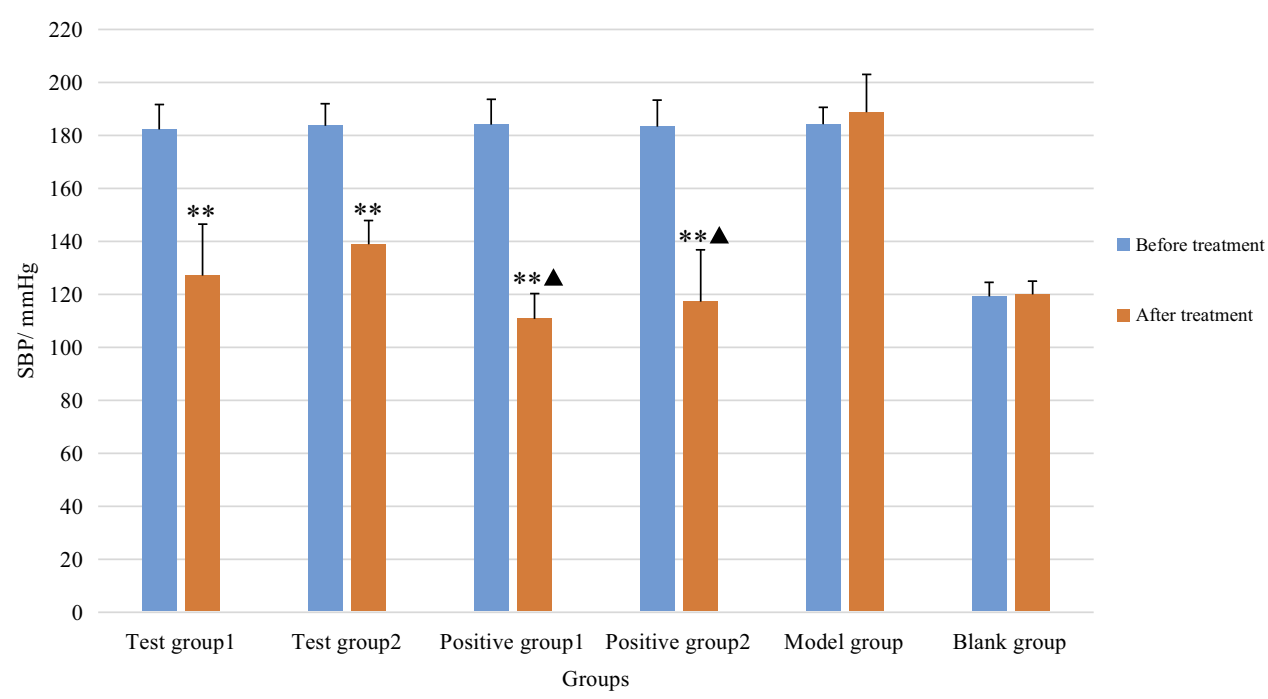

Figure 2 The antihypertensive effect of compound I 2 (Test group I) and ethyl ester of telmisartan (Test group 2). The differences between the before and after treatment of these groups were statistically significant (denoted by $* *$ for $p<0.01$ ); The differences of antihypertensive effect between test group and positive group 1 or positive group 2 were statistically significant (denoted by ${ }^{\wedge}$ for $p<0.05$ ).

(d) Positive group 2: telmisartan $11.43 \mathrm{mg} / \mathrm{kg}(0.022 \mathrm{mmol} /$ $\mathrm{kg})$.

\section{The Study on Blood Pressure Variability of Compound la}

These experimental procedures complied with regulations of the National Institutes of Health (NIH) of USA and conducted in accordance with the guidance of the Animal Ethics Committee of Beijing University of Chinese Medicine. The study protocol was approved by the Animal Ethics Committee of Beijing University of Chinese Medicine. Fifteen-week-old, male SD rats $(250 \mathrm{~g} \pm 20 \mathrm{~g})$ were purchased from the institute of Beijing Vital River Laboratory Animal Technology Co., Ltd. (Beijing, China). Before use in the study, all the rats were acclimatized in a controlled room at a constant temperature

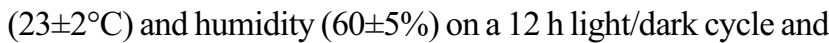
provided with standard diet and water for one week.

Sinoaortic denervation was performed in SD rats according to the method described in the literature. ${ }^{22,23}$

Four weeks after sinoaortic denervation, rats were anesthetized. A polyethylene catheter (PE-10 connected to PE-50) was chronically inserted into the lower abdominal aorta via the left femoral artery for the measurements of BP and heart period (HP), and another catheter (PE-50) was inserted into the left femoral vein for the examination of baroreflex function. The third catheter (PE-50) was inserted into the stomach for drug administration. These catheters were tunneled subcutaneously, exteriorized between the scapulae and fixed on a saddle. After two days of recovery, BP was continuously recorded in conscious unrestrained rats with a computerised technique (MPA-HBBS, Alcott Biotech, Shanghai, China). ${ }^{24,25}$

In $\mathrm{SAD}$ rats, arterial baroreflex function for heart-rate control was also assessed by intravenous injection of phenylephrine at $2-5 \mu \mathrm{g} / \mathrm{kg}$. For SAD rats that exhibited a bradycardia of less than 20 beats/min, successful baroreceptor denervation was considered, and the samples were included in the study.

The standard deviation (SD) of beat-to-beat BP values as an index of BPV including SBPV and DBPV.

The $20 \mathrm{SAD}$ rats were randomly divided into two groups, each group of 10 . One group of SAD rats were given compound 1a; One group of SAD rats was given telmisartan and ferulic acid.

Amount of medicine given:

(a) Test group: compound 1a $15.65 \mathrm{mg} / \mathrm{kg}(0.022 \mathrm{mmol} /$ $\mathrm{kg}$ );

(b) Positive group: telmisartan $11.43 \mathrm{mg} / \mathrm{kg}(0.022 \mathrm{mmol} /$ $\mathrm{kg})+$ ferulic acid $4.31 \mathrm{mg} / \mathrm{kg}(0.022 \mathrm{mmol} / \mathrm{kg})$.

After approximately 4-h habituation to BP recording environment, the BP signal was recorded for half an hour as basal (pre-drug) value. The drug was then administered via the catheter of gastric fistula. 3.5h after administration of compound 1a and telmisartan+ferulic acid, the BP signal was recorded for half an hour as post-drug value.

\section{Study on Antihypertensive Activity in vitro}

The activity test of the compounds involved in this study was based on calcium flow detection. The calcium flow 
changes of HEK-G ${ }_{\alpha} 15 /$ AT1, HEK-G ${ }_{\alpha} 15 /$ ETA and HEK-G $\mathrm{G}_{\alpha} 15 /$ ETB cells labelled with fluorescent dyes were detected using the FlexStation instrument. In the FlexStation of fluorescence imaging analysis system, the excitation wavelength was set to $485 \mathrm{~nm}$, and the emission wavelength was set to $525 \mathrm{~nm}$. The cells were inoculated with a density of $4 \times 10^{4} /$ well in a 96 -hole black wall transparent plate pre-coated by Matrigel ${ }^{\circledR}$ Matrix and cultured in a $\mathrm{CO}_{2}$ incubator at $37^{\circ} \mathrm{C}$. In the calcium flow test, the cell culture medium was removed, and the determination component of $100 \mu \mathrm{L}$ of calcium ions was added to each pore. The cells were placed into the incubator at $37^{\circ} \mathrm{C}$ and avoided light to incubate for $30 \mathrm{~min}$.

The agonist was prepared to $5 \times$ test concentration, 25 $\mu \mathrm{L}$ of compound solutions was added to the cell at a rate of $26 \mu \mathrm{L} / \mathrm{s}$, and calcium flow data were collected after adding compounds for $2 \mathrm{~s}$. For the detection of the activity of antagonist, different concentrations of antagonists $(30,25,20,15,10,5$ and $0 \mu \mathrm{M})$ were mixed with agonists of the same concentration to form $5 \times$ test concentration, and $25 \mu \mathrm{L}$ of compound solution was added to the cell at the rate of $26 \mu \mathrm{L} / \mathrm{s}$.

\section{Study on Pharmacokinetics}

These experimental procedures complied with regulations of the National Institutes of Health (NIH) of USA and conducted in accordance with the guidance of the Animal Ethics Committee of Beijing University of Chinese Medicine. The study protocol was approved by the Animal Ethics Committee of Beijing University of Chinese Medicine. Seventeen-week-old, Wistar rats
$(280 \pm 20 \mathrm{~g})$ were purchased from the Institute of Beijing Vital River Laboratory Animal Technology Co., Ltd. (Beijing, China). Before usage in the study, all rats were acclimatized in a controlled room at a constant temperature $\left(23 \pm 2^{\circ} \mathrm{C}\right)$ and humidity $(60 \% \pm 5 \%)$ on a $12 \mathrm{~h} \mathrm{light/dark} \mathrm{cycle} \mathrm{and} \mathrm{provided} \mathrm{with} \mathrm{standard} \mathrm{diet}$ and water for one week. The 80 Wistar rats (half male and half female) were randomly divided into ten groups, each group of 8 . They were given ferulic acid or caffeic acid alone, ferulic acid/caffeic acid + telmisartan, and twin drugs. Blood samples were collected from rat orbital vein plexus. Approximately $0.5 \mathrm{~mL}$ of blood samples were collected, heparin anticoagulant was added, centrifugation was conducted at $5000 \mathrm{r} / \mathrm{min} 10 \mathrm{~min}$, and the upper plasma was absorbed and stored at $-40^{\circ} \mathrm{C}$ for use. The plasma concentration at different time points was measured by HPLC (Agilent Technologies Inc, America). These twin drugs had good stability as determined by testing the room temperature stability and freeze-thaw stability. Kinetica 4.4 software was used to fit pharmacokinetic parameters.

\section{Results and Discussions}

\section{Synthesis}

In the current study, a set of novel compounds were synthesized, among which compounds 1a, 1b, 1c, 1d, 1f have not been previously reported. Schemes 1-3 showed the synthetic routes of compounds 1a-1f.

\section{The Ester of Telmisartan and Ferulic Acid Methyl or Ethyl Ester}

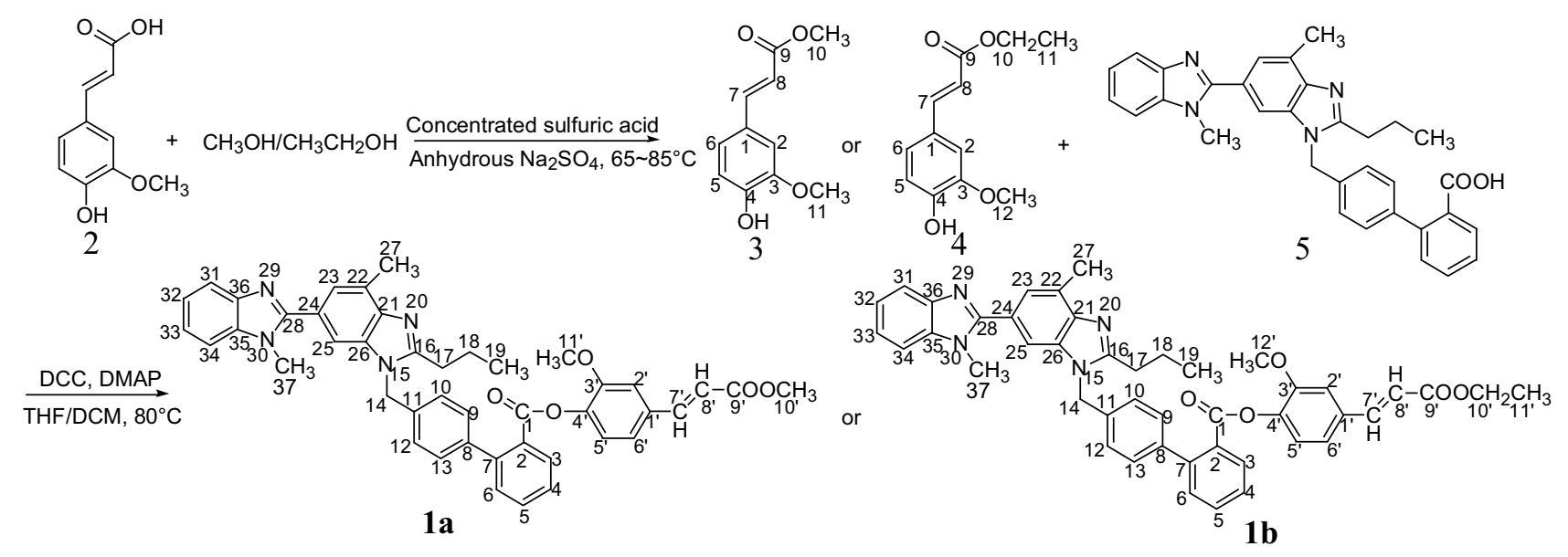

Scheme I Synthesis of compound Ia-lb. 
The Ester of Telmisartan and Caffeic Acid Methyl or

Ethyl Ester (The Atomic Number of Compounds

Were the Same as Compounds 3, 4, Ia and Ib)

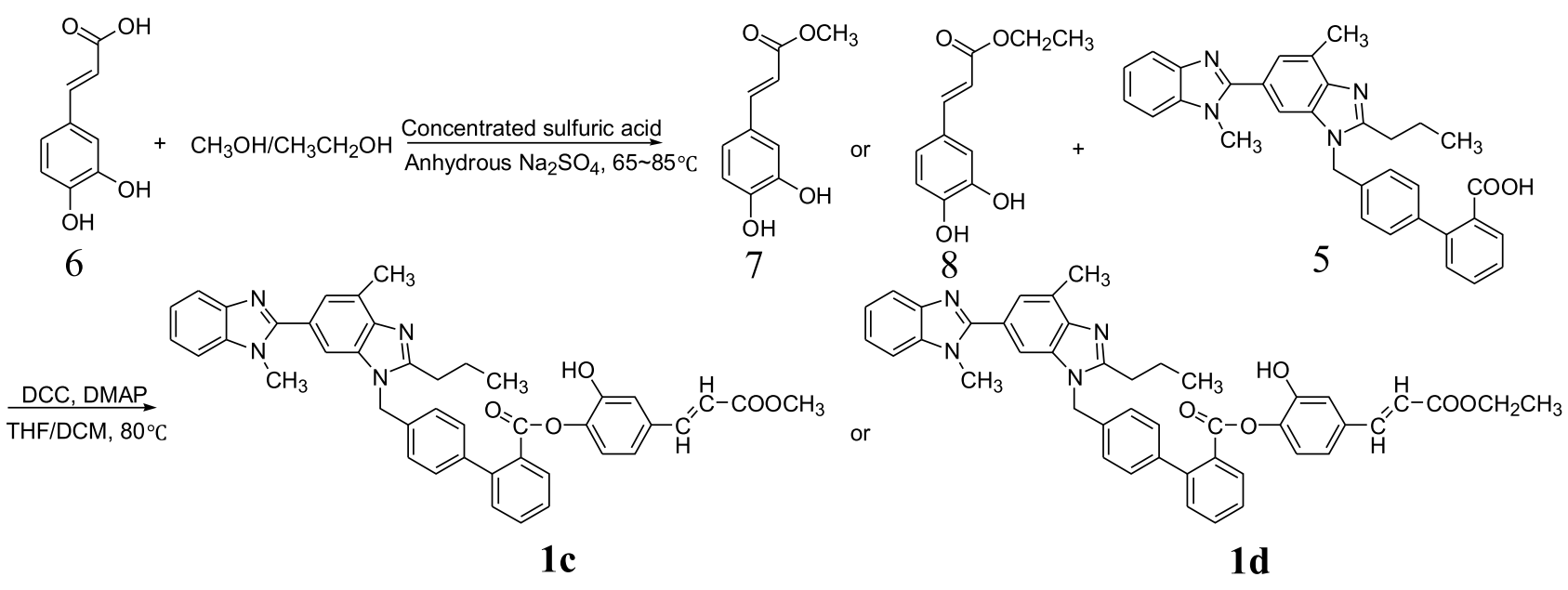

Scheme 2 Synthesis of compound Ic-Id.

The Ester of Telmisartan and Ferulic Acid or Caffeic Acid (The Atomic Number of Compounds Were the Same as Compounds 3, 4, Ia and Ib)

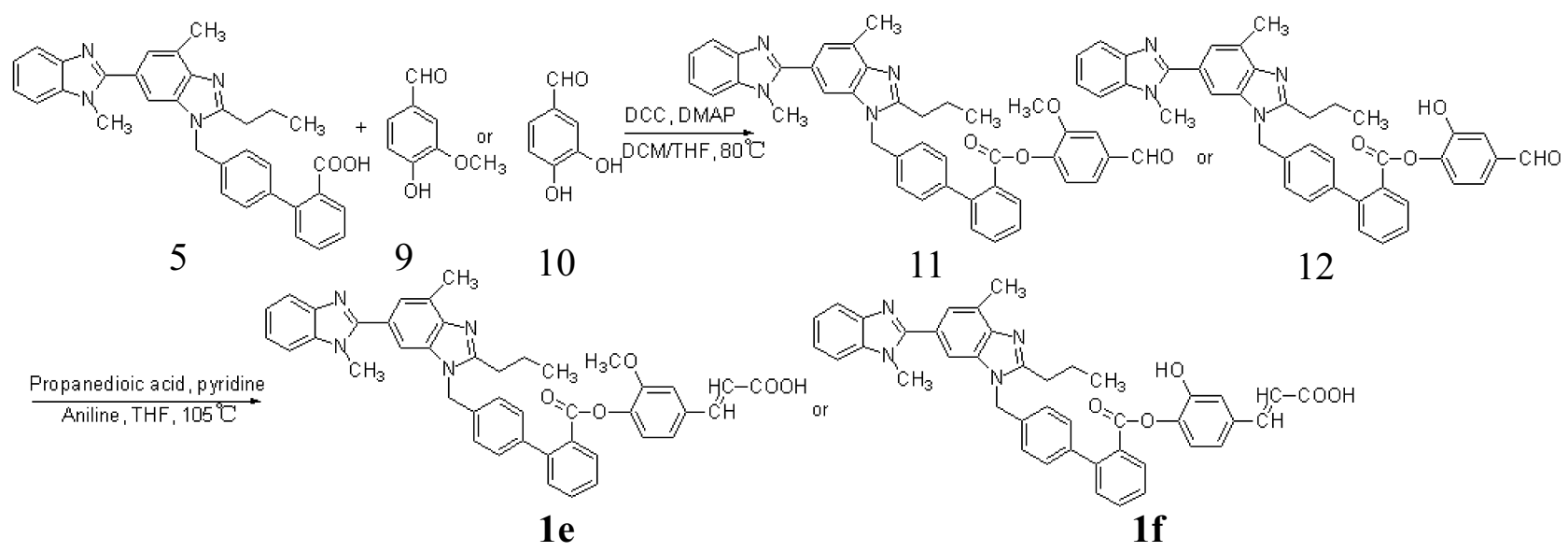

Scheme 3 Synthesis of compound Ie-If.

\section{Biological Activity in vivo}

\section{Study of the Antihypertensive Activity of the Target} Compounds Ia-If

Figures 1 and 2 show the antihypertensive effect of these compounds.

The positive group 1 comprised telmisartan combined with FLA, and the dose was the same as that in test groups (compound 1a, 1b, 1e). The positive group 2 comprised telmisartan combined with caffeic acid, and the dose was the same as that in test groups (compounds $\mathbf{1 c}, \mathbf{1 d}$ and $\mathbf{1 f}$ ). The positive group 3 comprised telmisartan, and the dose was the same as that in the six test groups. As shown in Figure 1, compound 1a had better antihypertensive effect than the other twin drugs, and its antihypertensive effect was better than that of positive group $3(p<0.05)$. The antihypertensive effects of the other twin drugs were equal to or weaker than that of the positive groups $(p<0.05)$. Among them, the antihypertensive effects of 
compounds 1e and 1f were poor, which may be due to the exposure of carboxyl groups, thus increasing the polarity and affecting their absorption and metabolism in the body. Moreover, when the six twin drugs were studied for efficacy, the positive groups tended to have cases of low or high blood pressure, while the test groups almost did not appear. Moreover, the twin drugs had a positive effect on keeping blood pressure stable.

There may be two reasons for the phenomenon: one reason was that after telmisartan and caffeic acid or ferulic acid become twin drugs, telmisartan could be slowly produced through metabolizing to avoid large doses directly acting on the target point in the body so that blood pressure was unstable; another reason was that it may be due to the effect of caffeic acid and ferulic acid produced through metabolizing. Although caffeic acid and ferulic acid were also present in the positive groups, the action time was less than that of caffeic acid and ferulic acid produced by the twin drugs.

Therefore, compound 12 and the ethyl ester of telmisartan were synthesized for antihypertensive activity testing. The experimental results (Figure 2) showed that compound 12 could not avoid BPV. Moreover, caffeic acid or ferulic acid had a certain effect in the twin drugs to avoid symptoms of BPV. The mechanism of this action may be related to the antagonistic activity on ET-1 of caffeic acid and ferulic acid. We also found that the antihypertensive effect of compound 12 was poor, and its activity was weaker than that of the positive group 2 $(p>0.05)$, indicating that ferulic acid could improve the antihypertensive effect of the twin drugs. These results indicated that telmisartan was esterified with other compounds or combination with caffeic acid and ferulic acid was not effective as the twin drugs. The results of the efficacy of ethyl ester of telmisartan showed its antihypertensive effect was weak ( $p<0.05)$, indicating that it may be not hydrolyzed in the body but acted directly in the form of ethyl ester of telmisartan, thus reducing the efficacy of this compound. ${ }^{19,20}$

\section{Biological Activity in vitro}

\section{The Cell Activity of Ang II-ATI Receptor Blocker}

Compound 1a had the best antagonistic activity on the Ang II-AT1 receptor in these twin drugs and was selected for further study of more gradient concentration. As shown in Figure 3, it turned out that $\mathrm{IC}_{50}$ of compound 1a was 340nM.

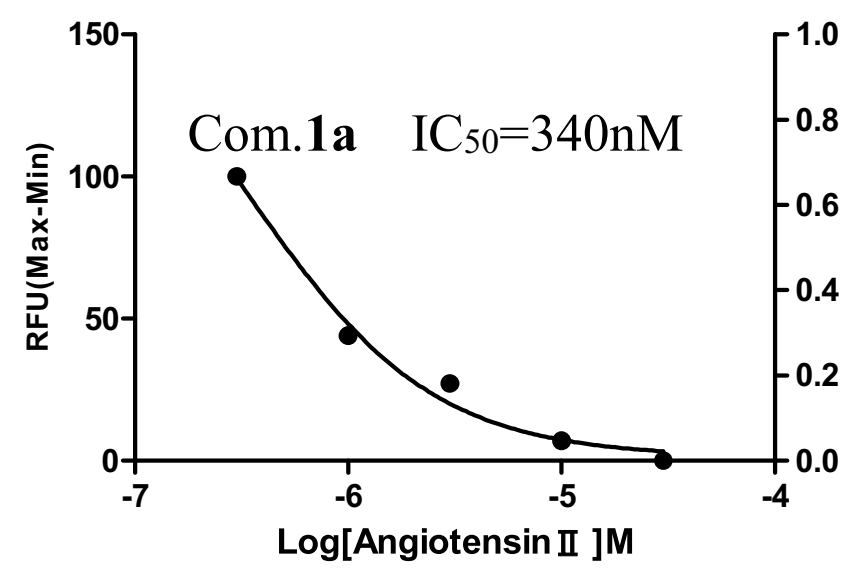

Figure 3 The cell activity of Ang II-ATI receptor blocker.

The Cell Activity of ETA and ETB Receptor Blocker These twin drugs could not antagonize ETA and ETB receptor.

The experimental results showed that compound 1a had the best antagonistic effect on the Ang II-AT1 receptor. However, it was two orders of magnitude higher than the positive drug telmisartan. The process of measuring the efficacy of these compounds in SHR rats showed that their antihypertensive effects were comparable to or better than that of telmisartan. All these results showed that the twin drugs worked by metabolizing and regenerating telmisartan and caffeic acid or ferulic acid in the body.

\section{Effects of Compound Ia on BPV}

The effects of compound 1a and telmisartan + ferulic acid on SBPV in SAD rats are shown in Figure 4. Compound 1a significantly decreased SBPV and decreased SBPV from $10.14 \pm 2.77 \mathrm{mmHg}$ to $7.98 \pm 2.66 \mathrm{mmHg}$, whereas the values of SBPV from telmisartan+ferulic acid were unchanged. Figure 5 shows the results of compound 1a and telmisartan+ferulic acid on DBPV in SAD rats. Compound 1a significantly decreased DBPV, similar to SBPV. DBPV decreased from $11.23 \pm 3.42 \mathrm{mmHg}$ to $8.66 \pm 2.97 \mathrm{mmHg}$. The values of DBPV from telmisartan + ferulic acid were unchanged. Hence, the formation of twin drugs through ester bond with ferulic acid and telmisartan could improve the effect of the combination of telmisartan and ferulic acid on BPV. Ferulic acid had a better effect on antagonizing ET-1 by binding with telmisartan, and this condition may be related to the improvement of metabolism in vivo of ferulic acid. 

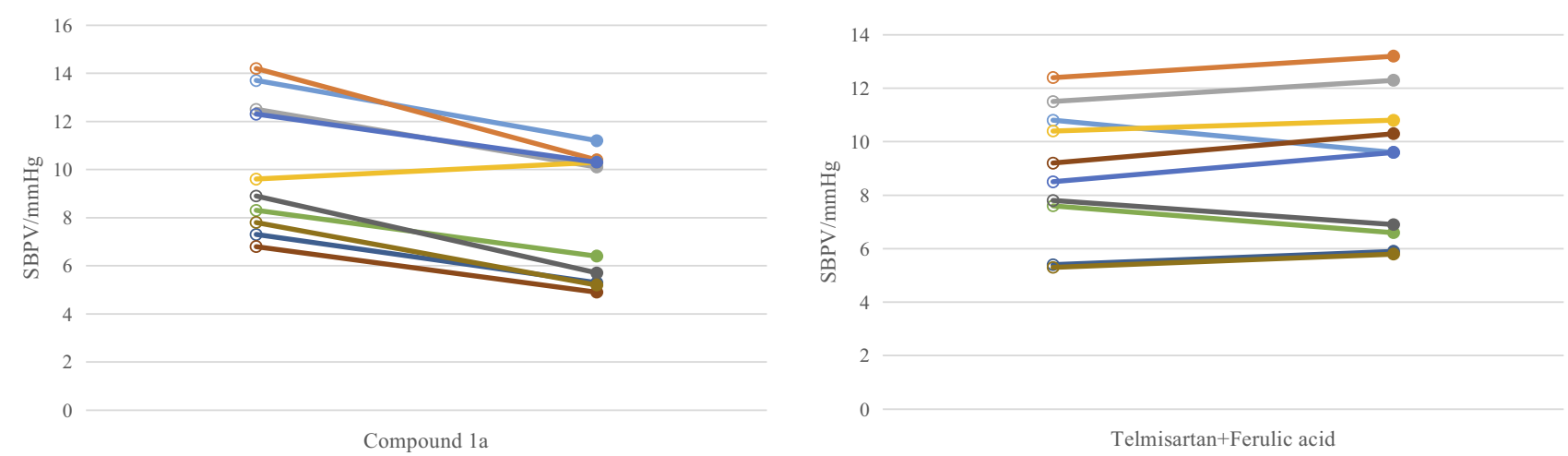

Figure 4 Systolic blood pressure variability (SBPV) responses to a single dose of compound Ia and telmisartan+ferulic acid in individual sinoaortic-denervated rats (SAD, $\mathrm{n}=10$ ). $\circ$, Before drug administration; $\bullet$, After drug administration.
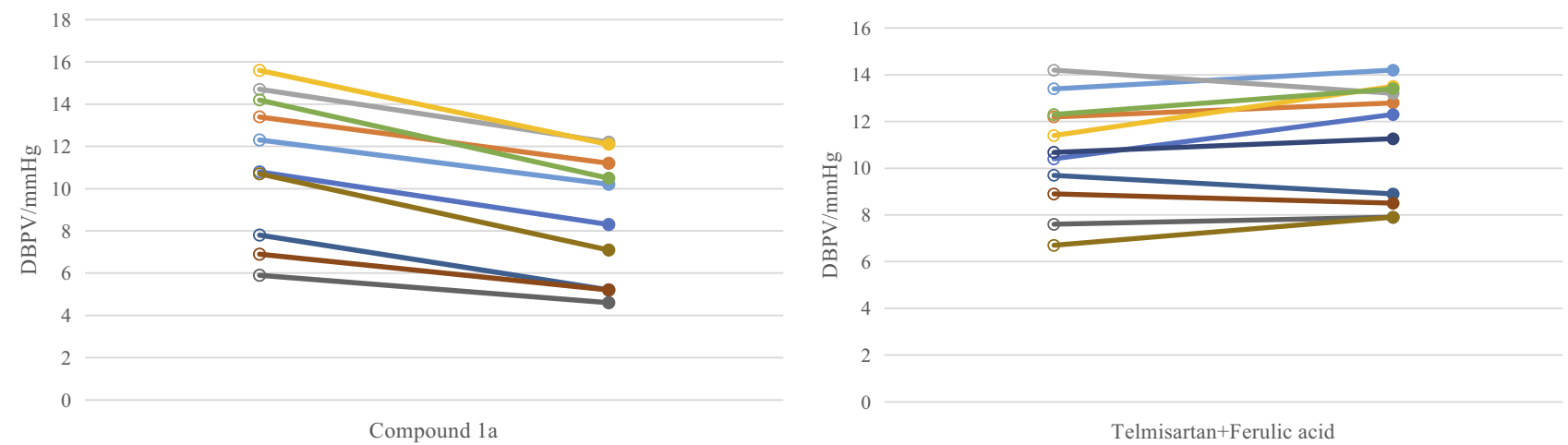

Figure 5 Diastolic blood pressure variability (DBPV) responses to a single dose of compound Ia and telmisartan+ferulic acid in individual sinoaortic-denervated rats (SAD, $\mathrm{n}=10$ ). $\circ$, Before drug administration; $\bullet$, After drug administration.

\section{Study on Pharmacokinetics} Study on the Pharmacokinetics of Ferulic Acid from the Six Twin Drugs

As shown in Figure 6 and Table 1, the differences of $\mathrm{C}_{\max 1}$ were not statistically significant compared with ferulic acid produced by the metabolism of compounds 1a, $1 \mathbf{b}, 1 \mathrm{e}$ and lone or combined administration $(p>0.05)$. This finding shows that the concentration of ferulic acid produced by the twin drugs hydrolyzed in vivo did not fluctuate greatly, and this condition was beneficial to maintain the efficacy of ferulic acid or inhibit its toxic and side effects. The $t_{\max 1}$ was prolonged, and the difference was statistically significant $(p<0.01$ or $p<0.05)$. The double peak absorption of ferulic acid produced by the metabolism of compounds $\mathbf{1 a}, \mathbf{1 b}$ and $\mathbf{1 e}$, and their $\mathrm{t}_{1 / 2}$ values were significantly extended $(p<0.01)$ compared with lone or combined administration. This process would greatly improve the action time of ferulic acid in vivo, and the

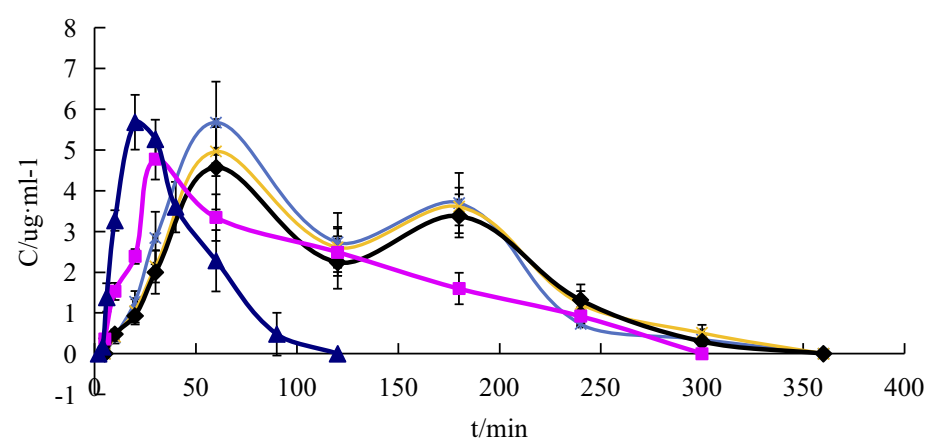
*- Ferulic acid from twin drugs of telmisartan and ferulic acid methyl ester
$\rightarrow$ Ferulic acid from twin drugs of telmisartan and ferulic acid ethyl ester
$\multimap$ Ferulic acid from twin drugs of telmisartan and ferulic acid
$\rightarrow$ Ferulic acid from combined administration

$\longrightarrow$ Ferulic acid alone

Figure 6 The drug-time curve of different forms of ferulic acid. 
Table I Main Pharmacokinetic Parameters of Ferulic Acid from Different Forms

\begin{tabular}{|c|c|c|c|c|c|}
\hline $\begin{array}{l}\text { Pharmacokinetic } \\
\text { Parameters }\end{array}$ & $\begin{array}{l}\text { Ferulic } \\
\text { Acid } \\
\text { (Alone) }\end{array}$ & $\begin{array}{l}\text { Ferulic Acid } \\
\text { (Combined } \\
\text { Administration) }\end{array}$ & $\begin{array}{l}\text { Ferulic Acid (from } \\
\text { Twin Drug of } \\
\text { Compound la) }\end{array}$ & $\begin{array}{l}\text { Ferulic Acid (from } \\
\text { Twin Drug of } \\
\text { Compound Ib) }\end{array}$ & $\begin{array}{l}\text { Ferulic Acid (from } \\
\text { Twin Drug of } \\
\text { Compound le) }\end{array}$ \\
\hline $\mathrm{C}_{\max \mathrm{I}} /$ ug $\mathrm{mL}^{-1}$ & $5.36 \pm 0.14$ & $4.98 \pm|.2|$ & $6.24 \pm 1.46$ & $5.18 \pm 0.79$ & $4.28 \pm 2.31$ \\
\hline$t_{\max } / \mathrm{h}$ & $0.35 \pm 0.10$ & $0.61 \pm 1.29 *$ & $1.00 \pm 0.00 \star \Delta \Delta$ & $1.00 \pm 0.00 \star \Delta \Delta$ & $1.38 \pm 0.45 \star \Delta \Delta$ \\
\hline $\mathrm{C}_{\max 2} /$ ug $\mathrm{mL}^{-1}$ & & & $3.79 \pm 1.27$ & $3.14 \pm 1.12$ & $3.52 \pm 1.6 \mathrm{I}$ \\
\hline $\mathrm{t}_{\max 2} / \mathrm{h}$ & & & $3.00 \pm 0.00$ & $3.00 \pm 0.00$ & $3.00 \pm 0.00$ \\
\hline$t_{1 / 2} / h$ & $0.67 \pm 0.17$ & $0.89 \pm 0.67$ & $3.21 \pm 0.81 \star \star \Delta \Delta$ & $2.34 \pm 1.27 \star \star \Delta \Delta$ & $2.01 \pm 0.34 \star \star \Delta \Delta$ \\
\hline $\begin{array}{l}A \cup C(0-t) / \\
\text { ug } h \cdot m^{-1}\end{array}$ & $2.53 \pm 0.41$ & $3.81 \pm 1.46 *$ & $6.63 \pm 0.31 \star \star \Delta \Delta$ & $6.89 \pm 1.12 \star \star \Delta \Delta$ & $5.21 \pm 0.62 \star \star \Delta \Delta$ \\
\hline $\begin{array}{l}\operatorname{AUC}(0-\infty) / \\
\text { ug } h \cdot \mathrm{mL}^{-1}\end{array}$ & $4.20 \pm 0.11$ & $4.77 \pm 3.42$ & $7.12 \pm 1.21 \star \star \Delta \Delta$ & $7.24 \pm 1.82 \star \star \Delta \Delta$ & $7.58 \pm 0.32 \star \star \Delta \Delta$ \\
\hline $\begin{array}{l}\operatorname{AUMC}(0-\mathrm{t}) / \\
\text { ug } \mathrm{h}^{2} \cdot \mathrm{mL}^{-1}\end{array}$ & $2.88 \pm 0.35$ & $5.72 \pm 1.68^{* *}$ & $15.58 \pm \mid .45 \star \star \Delta \Delta$ & $14.8 \mathrm{I} \pm 1.46 \star \star \Delta \Delta$ & $1 \mathrm{I} .5 \mathrm{I} \pm \mathrm{I} .35 \star \star \Delta \Delta$ \\
\hline $\begin{array}{l}\operatorname{AUMC}(0-\infty) / \\
\text { ug } h^{2} \cdot \mathrm{mL}^{-1}\end{array}$ & $6.23 \pm 0.87$ & $7.32 \pm 1.19$ & $\mid 8.42 \pm 0.51 \star \star \Delta \Delta$ & $18.21 \pm 0.86 \star \star \Delta \Delta$ & $16.86 \pm 1.47^{\star \star \Delta \Delta}$ \\
\hline MRT/h & I. $14 \pm 0.27$ & $1.50 \pm 1.24$ & $2.35 \pm 1.26 \star \Delta \Delta$ & $2.15 \pm 0.82 \star \Delta \Delta$ & $2.21 \pm 0.25 \star \Delta \Delta$ \\
\hline $\mathrm{T}_{1 / 2 \alpha /} \mathrm{h}$ & $0.42 \pm 0.21$ & $0.36 \pm 0.65$ & I. $14 \pm 0.47 \star \star \Delta \Delta$ & I. $14 \pm 1.28 \star \star \Delta \Delta$ & $1.12 \pm 0.38 \star \star \Delta \Delta$ \\
\hline $\mathrm{T}_{1 / 2 \beta /} \mathrm{h}$ & $0.43 \pm 0.30$ & $1.22 \pm 0.48^{* *}$ & $1.56 \pm 0.29^{\Delta \Lambda}$ & $1.12 \pm 1.13^{\Delta \Delta}$ & $1.41 \pm 0.42^{\Delta \wedge}$ \\
\hline
\end{tabular}

Notes: The differences of ferulic acid between the alone and combined administration were statistically significant (denoted by $*$ or $* *$ for $p<0.05$ or $p<0.01$, respectively); The differences of ferulic acid between the combined administration and the twin drug were statistically significant (denoted by $\star$ or $\star \star$ for $p<0.05$ or $p<0.01$, respectively); The differences of ferulic acid between the alone and the twin drug were statistically significant (denoted by $\Delta \mathbf{\Delta}$ for $p<0.0 \mathrm{I})$.

occurrence of double peak absorption can maintain the plasma concentration for a long time. This process is beneficial to maintain the function of ferulic acid on lowering blood pressure and BPV. The differences of AUC, AUMC, MRT, $\mathrm{T}_{1 / 2 \alpha}$ and $\mathrm{T}_{1 / 2 \beta}$ were also statistically significant $(p<0.01$ or $p<0.05)$ compared with ferulic acid produced by the metabolism of compounds 1a, 1b, 1e and lone or combined administration. Hence, the twin drugs of compounds $\mathbf{1 a}, \mathbf{1 b}$ and $\mathbf{1 e}$ could increase the bioavailability of ferulic acid, thus greatly improving the pharmaceutical properties of ferulic acid. The difference of $\mathrm{C}_{\max 1}$ was not statistically significant compared with the lone and combined administration of ferulic acid $(p>0.05)$, but the $\mathrm{C}_{\max 1}$ of ferulic acid produced by the combined administration was smaller than that of the lone administration. This point was contrary to the metabolism of caffeic acid, possibly because the combination of telmisartan and ferulic acid would prevent the absorption of ferulic acid. The differences of $\operatorname{AUC}(0-t)$ and $\operatorname{AUMC}(0-t)$ were also statistically significant $(p<0.01$ or $p<0.05)$ compared with ferulic acid produced by lone and combined administration. Moreover, combined administration yielded ferulic acid with good bioavailability, possibly because telmisartan could affect the metabolism of ferulic acid in the body. In other words, when ferulic acid was used in combination with telmisartan, the absorption of ferulic acid would be reduced, but the metabolism of ferulic acid would be slowed down. The pharmacokinetic parameters of compound 1e were worse than compounds 1a and 1b. This condition may be related to ferulic acid in compound 1e with exposed carboxyl group, resulting in the poor absorption and metabolism of ferulic acid in vivo.

As shown in Figure 7 and Table 2, the differences of $\mathrm{C}_{\max 1}$ were statistically significant $(p<0.01$ or $p<0.05)$ compared with caffeic acid from combined administration and the metabolism of compounds 1c, 1d and 1f. The $\mathrm{C}_{\max 1}$ of combined administration of caffeic acid was better than that of alone administration $(p<0.05)$. Hence, the combination of caffeic acid and telmisartan could enhance the absorption of caffeic acid and could slow down its metabolism in the body, resulting in the highest $\mathrm{C}_{\max 1}$. The $\mathrm{t}_{\max 1}$ was prolonged, and the differences were statistically significant $(p<0.01)$ compared with caffeic acid produced by the metabolism of compounds 1c, 1d 1f and lone or combined administration. This finding indicates that the twin drugs had certain metabolic processes in vivo, yielding the caffeic acid produced by the twin drugs with longer $t_{\max 1}$. The double peak absorption of caffeic acid produced by the metabolism of compounds 1c, 1d and 1 f and their $t_{1 / 2}$ were also significantly extended 


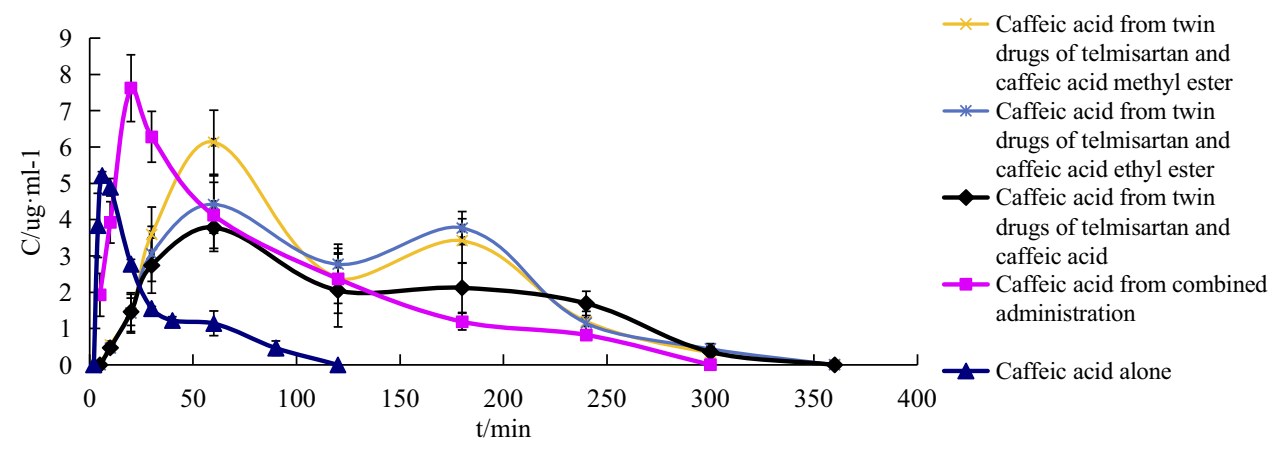

Figure 7 The drug-time curve of different forms of caffeic acid.

$(p<0.01)$ compared with lone or combined administration. This showed that caffeic acid through the formation of twin drugs could also make their drug concentration in the body can be maintained high for a long time, which was also conducive to caffeic acid played its corresponding treatment. The differences of AUC, AUMC, MRT, $\mathrm{T}_{1 / 2 \alpha}$ and $\mathrm{T}_{1 / 2 \beta}$ were also statistically significant $(p<0.01$ or $p<0.05)$ compared with caffeic acid produced by the metabolism of compounds 1c, $\mathbf{1 d}, \mathbf{1 f}$ and lone or combined administration. This finding shows that the twin drug of compounds 1c, 1d and 1f could increase the bioavailability of caffeic acid. Hence, the combined administration of caffeic acid could produce a rapid $t_{\max 1}$ in the body, but its elimination in the body remained relatively rapid.
Although the $t_{\max 1}$ of caffeic acid produced by twin drugs was delayed, the retention time in vivo was long, and the double peak absorption could keep the high concentration of caffeic acid, which was conducive to achieve a long-term effect. The differences of $\mathrm{AUC}(0-\mathrm{t})$, AUC $(0-\infty), \operatorname{AUMC}(0-\mathrm{t})$ and $\operatorname{AUMC}(0-\infty)$ were also statistically significant $(p<0.01)$ compared with caffeic acid produced by lone and combined administration, and combined administration yielded caffeic acid with good bioavailability. The pharmacokinetic parameters of compound $\mathbf{1 f}$ were worse than compounds $\mathbf{1 c}$ and $\mathbf{1 d}$. This condition may be related to caffeic acid in compound $\mathbf{1 f}$ with exposed carboxyl group, resulting in the poor absorption and metabolism of caffeic acid in vivo. ${ }^{21}$

Table 2 Main Pharmacokinetic Parameters of Caffeic Acid from Different Forms

\begin{tabular}{|c|c|c|c|c|c|}
\hline $\begin{array}{l}\text { Pharmacokinetic } \\
\text { Parameters }\end{array}$ & $\begin{array}{l}\text { Caffeic } \\
\text { Acid } \\
\text { (Alone) }\end{array}$ & $\begin{array}{l}\text { Caffeic Acid } \\
\text { (Combined } \\
\text { Administration) }\end{array}$ & $\begin{array}{l}\text { Caffeic Acid (from } \\
\text { Twin Drug of } \\
\text { Compound Ic) }\end{array}$ & $\begin{array}{l}\text { Caffeic Acid (from } \\
\text { Twin Drug of } \\
\text { Compound Id) }\end{array}$ & $\begin{array}{l}\text { Caffeic Acid (from } \\
\text { Twin Drug of } \\
\text { Compound If) }\end{array}$ \\
\hline $\mathrm{C}_{\max \mathrm{I}} /$ ug $\mathrm{mL}^{-1}$ & $5.22 \pm 0.10$ & $7.62 \pm 0.92 *$ & $5.31 \pm 1.19^{\star}$ & $4.73 \pm 1.28 \star$ & $3.85 \pm 1.02 \star \star \Delta$ \\
\hline $\mathrm{t}_{\max } / \mathrm{h}$ & $0.10 \pm 0.00$ & $0.33 \pm 0.08 * *$ & $1.00 \pm 0.00 \star \star \Delta \Delta$ & $1.00 \pm 0.00 \star \star \Delta \Delta$ & $1.00 \pm 0.00 \star \star \Delta \Delta$ \\
\hline $\mathrm{C}_{\max 2} /$ ug $\cdot \mathrm{mL}^{-1}$ & & & $3.89 \pm 1.76$ & $3.65 \pm 1.62$ & $3.92 \pm 1.12$ \\
\hline $\mathrm{t}_{\max 2} / \mathrm{h}$ & & & $3.00 \pm 0.00$ & $3.00 \pm 0.00$ & $2.95 \pm 1.32$ \\
\hline $\mathrm{t}_{1 / 2} / \mathrm{h}$ & $0.46 \pm 0.07$ & $0.67 \pm 0.19$ & $1.89 \pm 0.87 \star \star \Delta \Delta$ & $2.31 \pm 0.46 \star \star \Delta \Delta$ & $2.12 \pm 1.21 \star \star \Delta \Delta$ \\
\hline $\begin{array}{l}A \cup C(0-t) / \\
\text { ug } h \cdot \mathrm{mL}^{-1}\end{array}$ & $1.89 \pm 0.30$ & $5.06 \pm 0.61 * *$ & $5.45 \pm 0.32^{\wedge \Lambda}$ & $5.89 \pm 0.42^{\Delta \Lambda}$ & $4.32 \pm 1.21^{\Delta \wedge}$ \\
\hline $\begin{array}{l}\mathrm{AUC}(0-\infty) / \\
\text { ug } h \cdot \mathrm{mL}^{-1}\end{array}$ & $2.76 \pm 0.47$ & $5.5 I \pm 0.61 * *$ & $6.76 \pm 0.67^{\Delta \Lambda}$ & $6.44 \pm 1.13^{\Delta \Lambda}$ & $5.89 \pm 1.98^{\Delta \Lambda}$ \\
\hline $\begin{array}{l}\operatorname{AUMC}(0-\mathrm{t}) / \\
\text { ug } \mathrm{h}^{2} \cdot \mathrm{mL}^{-1}\end{array}$ & $1.30 \pm 0.25$ & $5.3 I \pm 0.7 \mid * *$ & $8.56 \pm 0.35 \star \Delta \Delta$ & $8.72 \pm 0.91 \star \Delta \Delta$ & $5.79 \pm 1.21^{\Delta \Delta}$ \\
\hline $\begin{array}{l}\operatorname{AUMC}(0-\infty) / \\
\text { ug } h^{2} \cdot \mathrm{mL}^{-1}\end{array}$ & $2.66 \pm 0.96$ & $6.79 \pm 1.17 * *$ & $9.89 \pm 0.76 \star \star \Delta \Delta$ & $9.73 \pm 0.21 \star \star \Delta \Delta$ & $8.94 \pm 2.13 \star \star \Delta \Delta$ \\
\hline $\mathrm{MRT} / \mathrm{h}$ & $0.69 \pm 0.12$ & $1.05 \pm 0.17 * *$ & $1.57 \pm 0.45 \star \Delta \Delta$ & $1.48 \pm 0.90 \star \Delta \Delta$ & $1.34 \pm 1.30^{\Delta \Lambda}$ \\
\hline $\mathrm{T}_{1 / 2 \alpha /} \mathrm{h}$ & $0.52 \pm 0.47$ & $0.36 \pm 0.27$ & $1.32 \pm 0.51 \star \star \Delta \Delta$ & $1.74 \pm 0.64 \star \star \Delta \Delta$ & $1.87 \pm 1.12 \star \star \Delta \Delta$ \\
\hline $\mathrm{T}_{1 / 2 \beta /} \mathrm{h}$ & $0.33 \pm 0.40$ & $0.46 \pm 0.15$ & $1.62 \pm 0.31 \star \star \Delta \Delta$ & $\mathrm{I} .14 \pm 0.52 \star \star \Delta \Delta$ & $1.24 \pm 0.41 \star \star \Delta \Delta$ \\
\hline
\end{tabular}

Notes: The differences of caffeic acid between the alone and combined administration were statistically significant (denoted by $*$ or $* *$ for $p<0.05$ or $p<0.0$ I, respectively); The differences of caffeic acid between the combined administration and the twin drug were statistically significant (denoted by $\star$ or $\star \star$ for $p<0.05$ or $p<0.0 \mathrm{I}$, respectively); The differences of caffeic acid between the alone and the twin drug were statistically significant (denoted by $\Delta$ or $\Delta \mathbf{\Delta}$ for $p<0.05$ or $p<0.0$ I, respectively). 
Through the above studies, caffeic acid and ferulic acid could increase their bioavailability by forming twin drugs with telmisartan.

\section{Conclusions}

The antihypertensive effects of the six twin drugs were studied in the animal model of SHR rats. Results showed that the positive group showed symptoms of high or low blood pressure, while the twin drugs did not show these symptoms during the antihypertensive process. This condition occurred possibly because after forming twin drugs, hydrolysis occurred, thus preventing the concentration of telmisartan and ferulic acid or caffeic acid in the body to increase abruptly and avoiding the appearance of symptoms of high or low blood pressure. ${ }^{26-29}$ To verify this result, we studied antihypertensive effects of the ethyl ester of telmisartan and compound 12. After studying the pharmacodynamics, results showed that compound 12 could not avoid these symptoms, indicating that only caffeic acid and ferulic acid could avoid these symptoms if they formed twin drugs with telmisartan, and the release of telmisartan by hydrolysis was not a good way to avoid BPV. The efficacy of ethyl ester of telmisartan showed that no symptoms of high or low blood pressure appeared, but its antihypertensive effect was weak, and the difference was statistically significant compared with that of telmisartan $(p<0.05)$. It may be that it did not hydrolyse in the body but acted directly in the form of ethyl ester of telmisartan, which reduced the efficacy of the drug. Among the six twin drugs, the effect of compound 1a was the best and was even better than that of telmisartan $(p<0.05)$. Hence, we studied the effects of compound 1a on BPV.

The effects of the compound 1a on SBPV and DBPV in SAD rats showed that compound 1a significantly decreased SBPV and DBPV compared with telmisartan + ferulic acid $(p<0.05)$. Hence, telmisartan and ferulic acid methyl ester formed twin drugs that could improve the effect of telmisartan on BPV.

Subsequently, the activity of Ang II-AT1 receptor blocker was tested on cell level. Among them, the effect of compound 1a was the best, but it was two orders of magnitude different from the $\mathrm{IC}_{50}$ of telmisartan. The results of this study verified that these twin drugs in vivo were metabolized to reproduce telmisartan and caffeic acid or ferulic acid to work and verified the results of pharmacokinetics.

The pharmacokinetics of six twin drugs were studied. Results showed that the twin drugs could be metabolized to reproduce ferulic acid and telmisartan or caffeic acid and telmisartan, and the bioavailability of caffeic acid and ferulic acid could be improved by forming twin drugs. The bioavailability of the caffeic acid and ferulic acid produced by combined administration was not as good as that of caffeic acid and ferulic acid produced by the twin drugs. During metabolism, double peak absorption was observed. The bioavailability of caffeic acid and ferulic acid from compounds 1a, 1b, 1c and 1d was superior to that of compounds 1e and 1f. The reason for this result may be the exposure of the carboxyl group of compounds $1 \mathrm{e}$ and 1f that resulted in a strong polarity of compounds $1 \mathrm{e}$ and 1f, which reduced the absorption of these two compounds. The bioavailability of caffeic acid and ferulic acid produced by combined administration was higher than that of lone administration, and the difference was statistically significant. In combined administration, telmisartan had different effects on the in vivo process of caffeic acid and ferulic acid. Hence, the $\mathrm{C}_{\max }$ of ferulic acid produced by combined administration was lower than that of lone administration. In short, it was demonstrated that telmisartan not only affected the absorption of caffeic acid and ferulic acid in rats, but also increased their bioavailability by forming twin drugs. The mechanism may be that after forming twin drugs, the in-vivo process of caffeic acid and ferulic acid was affected by the twin drugs and the telmisartan metabolized from twin drugs. Other mechanisms need to be further studied and demonstrated.

This type of twin drugs has certain reference and value for the research and development of new ARB drugs or new drugs to antagonize endothelin- 1 and provides reference for improving the bioavailability of certain small molecular compounds.

\section{Data Sharing Statement}

The data described in this article are openly available in the Open Science Framework at DOI:10.17605/OSF.IO/TPA6U.

\section{Acknowledgments}

This research was funded by the University-Level Autonomous Project of Beijing University of Chinese Medicine (No. 532/0100602077), PhD Research Foundation (No. 4600210). The authors are thankful to the Analytical and Testing Center of Beijing Normal University and the Experimental Animal Center of Beijing University of Chinese Medicine for their constant encouragement and support. 


\section{Disclosure}

The authors declare no conflicts of interest.

\section{References}

1. Gong X, Tang XJ, Han ZP, Xia BH. Evaluation of blood pressure smoothing index in comparison between lacidipine and telmisartan. Guide Chin Med. 2011;9:253-254.

2. Liu Y, Su Y, Tang JG. Telmisartan combined with amlodipine were used to improve the blood pressure variability in patients with type 2 diabetes and essential hypertension. $J$ Third Mil Med Univ. 2013;35:275-276.

3. Parati G, Schumacher H. Blood pressure variability over $24 \mathrm{~h}$ : prognostic implications and treatment perspectives. An assessment using the smoothness index with telmisartan-amlodipine monotherapy and combination. Hypertens Res. 2014;37:187-193. doi:10.1038/ hr.2013.145

4. Parati G, Dolan E, Ley L, Schumacher H. Impact of antihypertensive combination and monotreatments on blood pressure variability: assessment by old and new indices. Data from a large ambulatory blood pressure monitoring database. $J$ Hypertens. 2014;32:1326-1333. doi:10.1097/HJH.0000000000000169

5. Yu Q, Yao FY, Dai HX. Research on progress of blood pressure variability and target organ damage of essential hypertension. Chin J Evid Based Cardiovasc Med. 2018;10:508-510.

6. Mezue K, Goyal A, Pressman GS, Matthew R, Horrow JC, Rangaswami J. Blood pressure variability predicts adverse events and cardiovascular outcomes in SPRINT. $J$ Clin Hypertens(Greenwich). 2018;9:1-6.

7. Zhang HX, Fan QX, Xue SZ, Zhang M, Zhao JX. Twenty-four-hour blood pressure variability plays a detrimental role in the neurological outcome of hemorrhagic stroke. J Int Med Res. 2018;46:2558-2568. doi:10.1177/0300060518760463

8. Wilson JL, Warburton R, Taylor L, Toksoz D, Hill N, Polgar P. Unraveling endothelin-1 induced hypercontractility of human pulmonary artery smooth muscle cells from patients with pulmonary arterial hypertension. PLoS One. 2018;13:1-19. doi:10.1371/journal. pone.0195780

9. Park BG, Shin WS, Oh S, Park GM, Kim NI, Lee S. A novel antihypertension agent, sargachromenol D from marine brown algae, sargassum siliquastrum, exerts dual action as an L-type $\mathrm{Ca}^{2+}$ channel blocker and endothelin A/B2 receptor antagonist. Bioorg Med Chem. 2017;25:4649-4655. doi:10.1016/j.bmc.2017.07.002

10. Wang F, Liu M, Yang LC, et al. Caffeic acid, ferulic acid: a new kind of non-peptide endothelin antagonist. Chin J Clin Pharmacol Ther. 1999;4:85-92.

11. Alici O, Kavakli HS, Koca C, Altintas ND, Aydin M, Alici S. Value of caffeic acid phenethyl ester pretreatment in experimental sepsis model in rats. Mediators Inflamm. 2015;8:1-6. doi:10.1155/2015/ 810948

12. Wu L, Li X, Wang L, Tang Y, Xue M. Proliferative inhibition of danxiongfang and its active ingredients on rat vascular smooth muscle cell and protective effect on the VSMC damage induced by hydrogen peroxide. $J$ Ethnopharmacol. 2009;126:197-206. doi:10.1016/j.jep.2009.08.045

13. Kang BY, Kleinhenz JM, Murphy TC, Hart CM. The PPAR $\gamma$ ligand rosiglitazone attenuates hypoxia-induced endothelin signaling in vitro and in vivo. Am J Physiol Lung Cell Mol Physiol. 2011;301:L881-91. doi:10.1152/ajplung.00195.2011
14. Hassanzadeh P, Arbabi E, Atyabi F, Dinarvand R. Ferulic acid-loaded nanostructured lipid carriers: A promising nanoformulation against the ischemic neural injuries. Life Sci. 2018;193:64-76. doi:10.1016/j. Ifs.2017.11.046

15. Li J, Bai Y, Bai Y, et al. Pharmacokinetics of caffeic acid, ferulic acid, formononetin, cryptotanshinone, and tanshinone IIA after oral administration of Naoxintong capsule in rat by HPLC-MS/MS. Evid Based Complement Alternat Med. 2017;5:1-12.

16. Su MY, Zhou TT, Zhou MJ. Pharmacokinetics of caffeic acid in rats. China Pharm. 2008;19:1220-1222.

17. Wang SJ, Zhang ZQ, Zhao YH, Ruan JX, Li JL. Simultaneous quantification of chlorogenic acid and caffeic acid in rat plasma after an intravenous administration of mailuoning injection using liquid chromatography/mass spectrometry. Rapid Commun Mass Spectrom. 2006;20:2303-2308. doi:10.1002/(ISSN)1097-0231

18. Shi B, Yang L, Gao T. Pharmacokinetic profile and metabolite identification of bornyl caffeate and caffeic acid in rats by high performance liquid chromatography coupled with mass spectrometry. RSC $A d v$. 2019;9:4015-4027. doi:10.1039/C8RA07972B

19. Weifa Y, Zhiming Z, Haibo Z, Lingshuai H. Synthesis of telmisartan and its derivatives and evaluation of their biological activities. Chin J Org Chem. 2006;26(3):318-323.

20. Li Y-Q, Ji H, Zhang Y-H, et al. WB1106, a novel nitric oxide-releasing derivative of telmisartan, inhibits hypertension and improves glucose metabolism in rats. Eur J Pharmacol. 2007;577 (1-3):100-108. doi:10.1016/j.ejphar.2007.08.008

21. Jie Z, Sujun W, Benkun Y, Yunming Z, Linquan Z, Lingli W. Absolute bioavailability of caffeic acid in rats and its intestinal absorption properties. China J Chin Mater Med. 2013;38 (23):4152-4156.

22. Fuming S, Yufeng G, hehui X, et al. Arterial baroreflex function determines the survival time in lipopolysaccharide-induced shock in rats. Shock. 2004;21(6):556-560. doi:10.1097/01. shk.0000126647.51109.5c

23. Tao X, Zhang S-H, Shen F-M, et al. High level apoptosis is persistent in myocardiocytes of sinoaortic-denervated rats. $J$ Hypertens. 2004;22(3):557-563. doi:10.1097/00004872-200403000-00019

24. Wang J, Shen FM, Wang MW, Su DF. Effects of nine antihypertensive drugs on blood pressure variability in sinoaortic-denervated rats. Acta Pharmacol Sin. 2006;27(8):1013-1017. doi:10.1111/j.17457254.2006.00381.x

25. Fu YJ, Shu H, Miao CY, Wang MW, Su DF. Restoration of baroreflex function by ketanserin is not blood pressure dependent in conscious freely moving rats. J Hypertens. 2004;22:1165-1172. doi:10.1097/ 00004872-200406000-00018

26. Wang N, Ahmad H, Yongming J, et al. Identification of polygala oligosaccharide esters and their metabolites in rat plasma after oral administration of ethanol extract of Kai Xin San by UHPLC-MS. Acta Pharm Sin. 2017;52(10):1592-1598.

27. Wenbao L, Fanghua D, Changjun S. Recent progress in research on prodrugs of nucleoside drugs. Progress Pharm Sci. 2012;36 (07):300-307.

28. Xiuli L, Jingchao S, Zitao G, Dafang Z, Xiaoyan C. Carboxylesterase 2 and intestine transporters contribute to the low bioavailability of allisartan, a prodrug of Exp3174 for hypertension treatment in humans. Drug Metab Dispos. 2019;5:1-22.

29. Li Y, Wang Y, Zhang R, et al. Improving the oral bioavailability of tapentadol via a carbamate prodrug approach: synthesis, bioactivation, and pharmacokinetics. Drug Deliv Transl Res. 2018;8 (5):1335-1344. doi:10.1007/s13346-018-0524-6 


\section{Publish your work in this journal}

Drug Design, Development and Therapy is an international, peerreviewed open-access journal that spans the spectrum of drug design and development through to clinical applications. Clinical outcomes, patient safety, and programs for the development and effective, safe, and sustained use of medicines are a feature of the journal, which has also been accepted for indexing on PubMed Central. The manuscript management system is completely online and includes a very quick and fair peer-review system, which is all easy to use. Visit http://www. dovepress.com/testimonials.php to read real quotes from published authors.

Submit your manuscript here: https://www.dovepress.com/drug-design-development-and-therapy-journal 